\title{
An Extensive Review of Face Powder Formulation Considerations
}

\author{
Abdul Kader Mohiuddin \\ Dr. M. Nasirullah Memorial Trust, Tejgaon, Dhaka.
}

Corresponding Author: Abdul Kader Mohiuddin, Dr. M. Nasirullah Memorial Trust, Tejgaon, Dhaka. E-mail:trymohi@gmail.com Received date: 14 October, 2019; Accepted date: 23 October, 2019; Published date: 07 November, 2019

Citation: Abdul Kader Mohiuddin (2019) An Extensive Review of Face Powder Formulation Considerations, J.Dermatology and Dermatitis. 4 (3); DOI:10.31579/2578-8949/058

Copyright: (02019 Abdul Kader Mohiuddin, This is an open-access article distributed under the terms of The Creative Commons. Attribution License, which permits unrestricted use, distribution, and reproduction in any medium, provided the original author and source are credited.

\begin{abstract}
The face powder was demanded by many nations in the world in the beginning AD and in Asia white skin was believed to be the sign of aristocratism, membership of the elite, and yet, white color is the pure symbol of the internal beauty and nobility. In addition, some face powders are sold in varying specialty shades to suit different skin needs; for example, a face powder with a greenish tinge will minimize the appearance of redness, while a purple-tinted powder may help the appearance of sallow or yellow skin. There is a legitimate reason to use face powder, and the pharmacopeias prescribe them in the treatment of many skin affections. At all events the proper use of powder is beneficial, it lightly covers and unifies a complexion, hiding the ravages of time, improving even the beautiful face. Face powder comes in different shades to match varying skin tones, and it is a good idea to choose the skin tone that most closely matches the natural skin. This will help the makeup appear more natural; it should be virtually unnoticeable. It may be necessary to use different face powders for summer and winter, as the skin may become tanner in the summer, or drier and in need of extra moisture in the winter. They are of benefit in acne, freckles, sunburn and red nose. Beneath their attractive aspect and odor, face powders should be made by the perfumer to combine the qualities of an elegant cosmetic and therapeutic agent; they must primarily possess adherence, lightness and be transparent; secondly, they should be detergent and delicately absorbent in order to aid the natural functions of the skin, taking up the fatty matters not easily dislodged by water; they should also tend to increase the natural elasticity and regular functions of the skin.
\end{abstract}

Keywords: absorbency; adhesion; covering power; pressed powder; moisture absorption; fashionable; perspiration; oily secretions; cosmetic care product

\section{Background}

First made popular in the 1930 s, until recently, it's arguably lacked the finesse of modern makeup (like foundation) which, over the last decade, has been fine-tuned, finely milled and given a twenty-first century makeover. The use of 'paint' was criticized in Victorian times but pale, flawless skins were fashionable so many women resorted to face powders to cover blemishes like sunburn, spots and freckles. Perspiration and oily secretions could also be rectified with powder, making it useful in places where summers were warm and women were more likely to 'glow'. As a cosmetic care product, face powder appeared in the ancient Egypt when the Queen Cleopatra applied powder before applying makeup. White skin was the sign of high status in the society since wealthy women did not have to work in the open air under the heavy sun light and their face never got tanned. When tanned for any reason, the Egyptians concealed the bronze under the layers of powder. The ingredients used for powder were various substances, even very exotic. So, Cleopatra who was ready for everything scarifying for her beauty used the powder made from crocodile excrements. In Roman times (A.D. 100s), "chalk and vinegar face creams lightened the complexion, and finely ground orris root was used in face powder," reports Gabriella Hernandez's "Classic Beauty: The History of Makeup". The women would use the powder presented as the mixture of crushed chalk and lead extremely toxic and harmful for the health, though immediately concealing all defects and drawbacks of the skin under the layer of dangerous makeup. In spite of the obvious harmfulness for the skin, such mixture was highly appreciated, and only the most rich and wealthy Romans could afford it. The other, less wealthy Roman women were satisfied with application of mixture from wheat flour. And in Ancient China, rice powder was used to whiten and smooth out the complexion. Also, Japanese women and men commonly used the face powder made from rice flour, while in Europe such flour appeared a little bit later, in the 16th century, when rice was marketed in some of European countries including main cores of fashion and noble life, as France, Spain and England. The powder made from grinded rice was used to apply onto the face skin and wigs that became more massive. During the reign of Louis 15 th, the powder was made a cosmetic means by the favorite of the King, marquise de Pompadour. The court ladies applied the thick layer of powder onto the face, hands, and shoulders making them aristocratically pale and hiding the skin defects. The colorful powder became fashionable, when the tender pink powder was used to accentuate beauty of cheeks and the blue powder was applied under eyes. Later on, the powder disappeared from practice since in the end of the 17th century a plenty of wheat and rice flour was spent to make the powder to the extent that powder pro was officially forbidden in France first and then in other countries to produce powder to save the assets. And the powder sank into oblivion for almost a hundred years and healthy and tanned look came in fashion. The Queen Victoria of Great Britain was the one who prohibited using the makeup for the reason that it seemed vulgar. The face powder returned its fame in the beginning of the 20th century when theater actresses concealed skin defects under the layer of powder not only on the stage but in everyday life also. In the early 20th century Anthony Overton launched his first powder for Afro-Americans under High Brown Brand. Then in France the powder was invented similar to the face powder we use now. The base for the powder was the talk without harmful lead admixtures not irritating the skin. For several decades the cosmetic industry underwent sea changes 
and revolutions. And in 1923 the English Company Laughton \& Sons proceeded to manufacture the comfortable compact powder-cases with sponges, and in the fifties the legendary Hollywood stylist Max Factor launched affordable to actresses and ordinary woman a version of foundation powder for everyday use called "Pan Cake", that effectively conceal drawbacks.

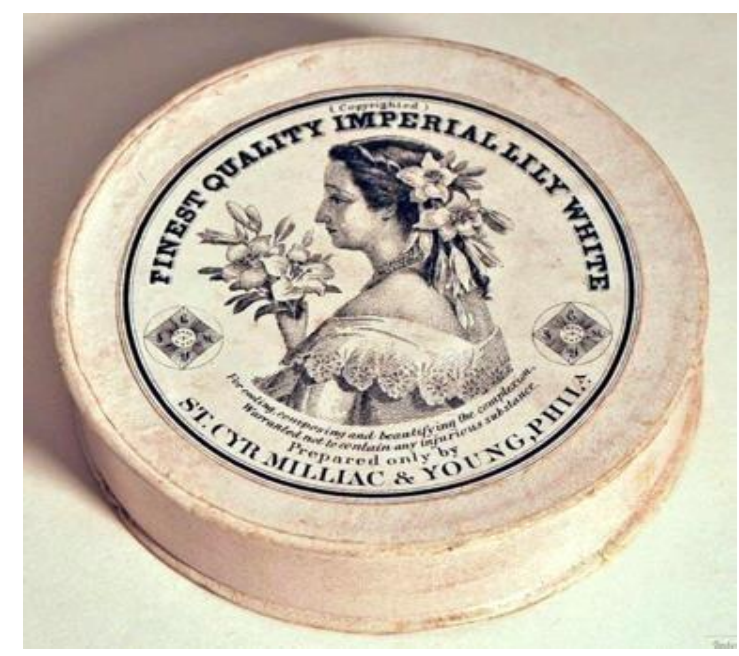

Figure 1a. 1871 Milliac \& Young powder box

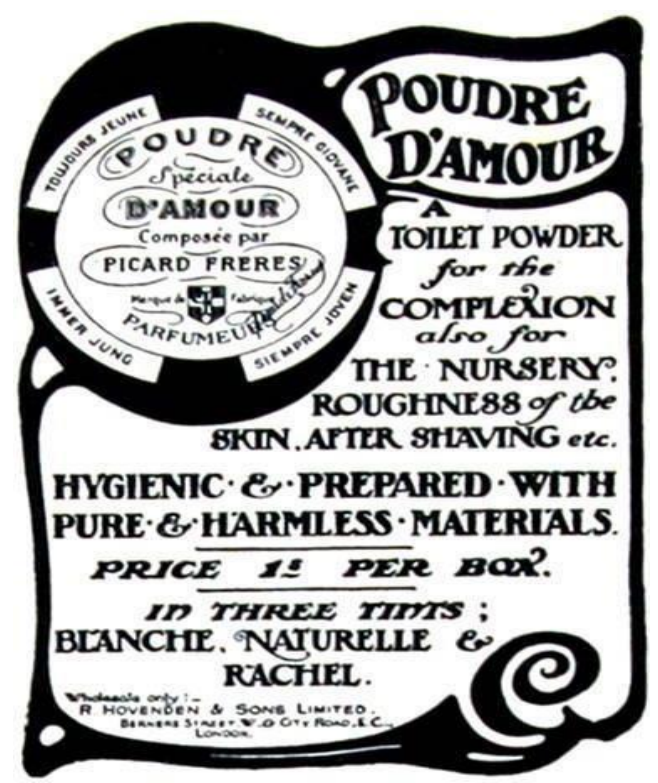

Figure 1c. 1903 Poudre D’Amour

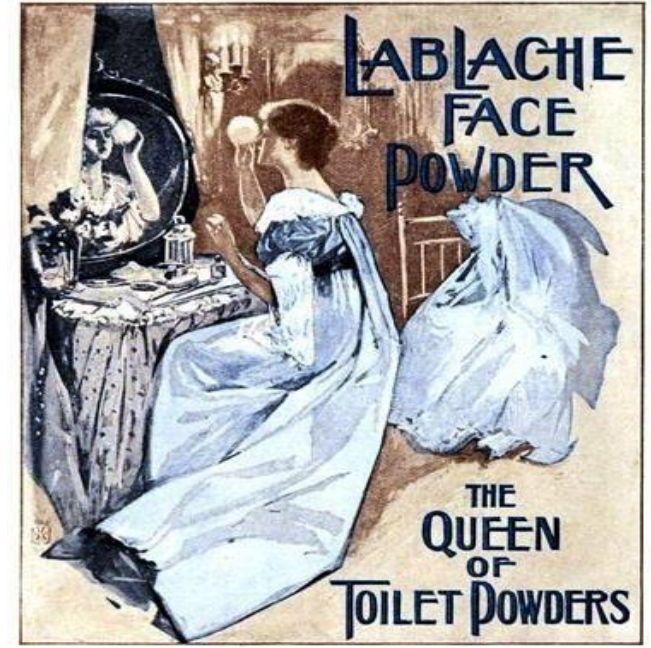

\section{SOCIETY WOMEN}

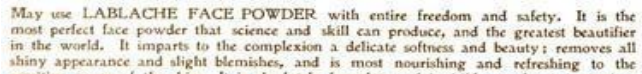

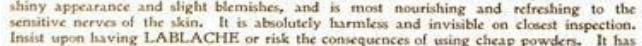

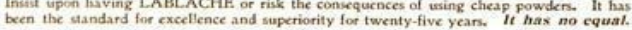

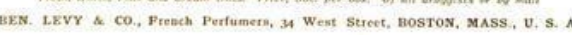

Figure 1b. 1896 LaBlache Face Powder.

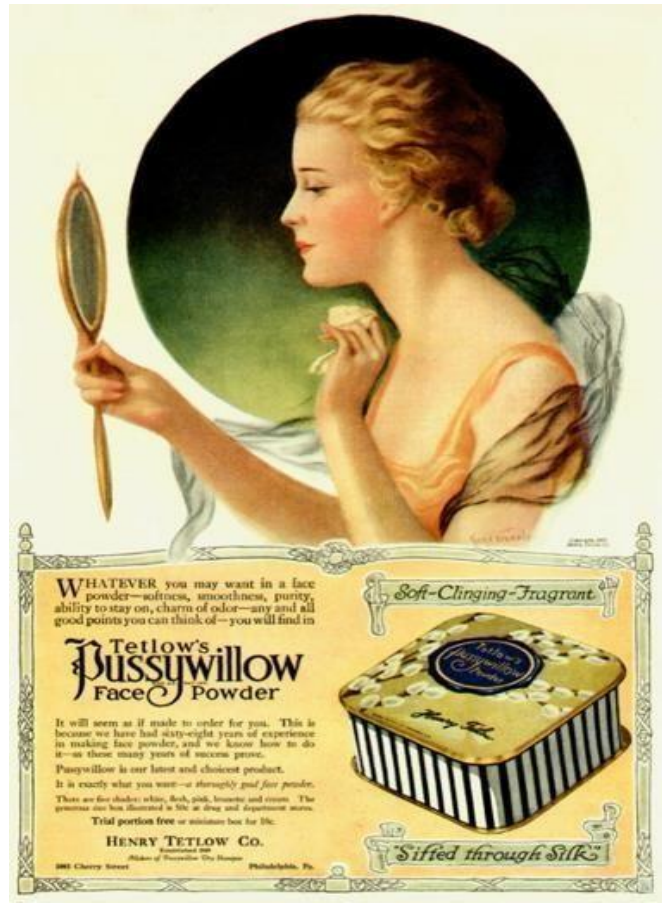

Figure 1d. 1917 Tetlow Pussywillow Face Powder. 


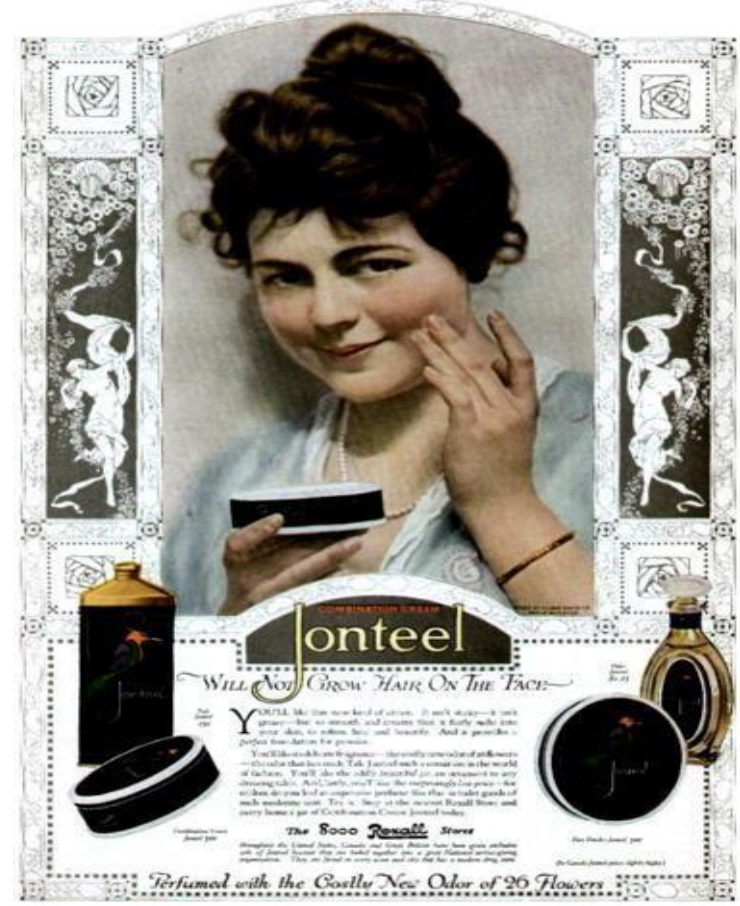

Figure 1e. 1919 Jonteel Face Powder.

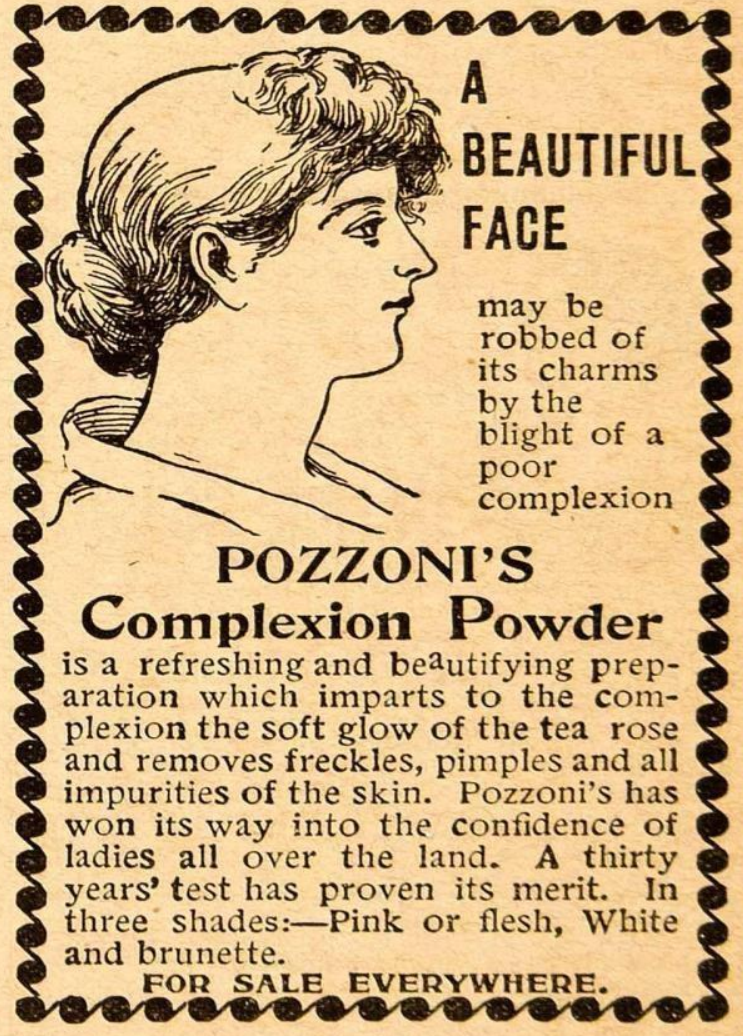

Figure 1f. 1894 Ad POZZONI'S Complexion Powder of Victorian era

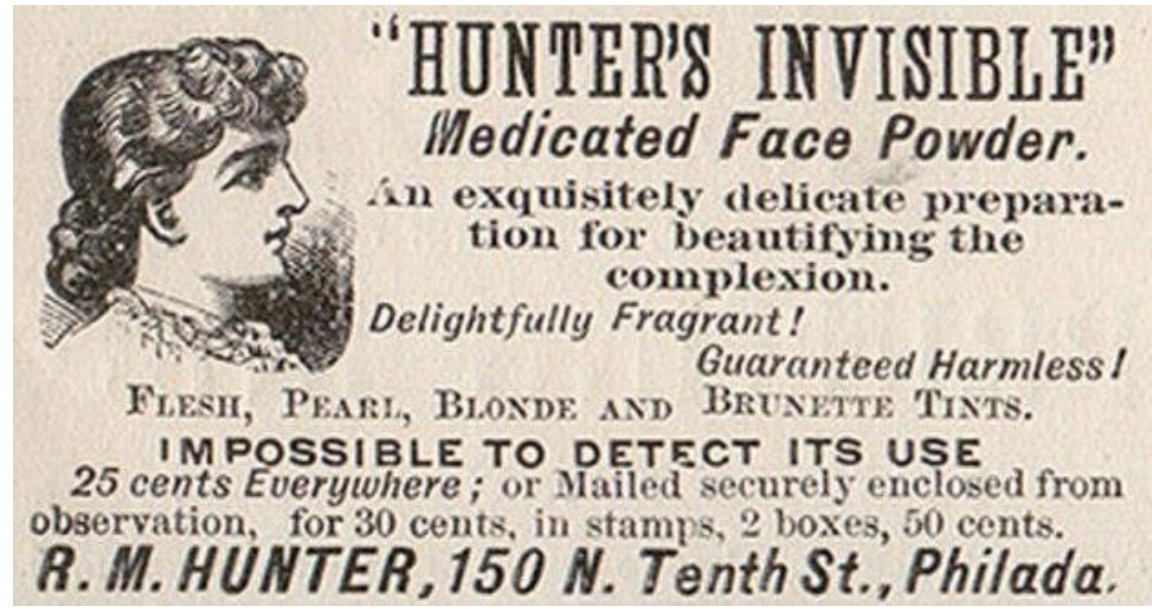

Figure 1g. Hunter's Invisible of Victorian Era. Like several other Victorian beauty techniques, lead cosmetics often caused problems it was meant to remedy. Combining lead face powders and paints with corrosive washes resulted in wounds and scars. Women tried to hide the blemishes beneath heavier layers of lead makeup, which made the problem worse. These thick layers of make-up cracked like porcelain if a woman was too expressive. Since women were expected to be naturally beautiful during the era, appearing at a social event with cracking face paste would have been extremely mortifying. Though face powders like this one claimed to be harmless, women rarely knew the ingredients. To cover unsightly blemishes and scars, women turned to face paints and powders. Some of these concoctions were rather mild, containing ingredients like rice powder, zinc oxide, or the extremely expensive blend of chloride of bismuth and talc. Others were made of lead flakes. Not only is lead highly toxic, it is easily absorbed through the skin. Side effects of lead poisoning include headache, constipation, memory loss, pain and numbness, and if ingested in large enough quantities, will cause paralysis and death. 


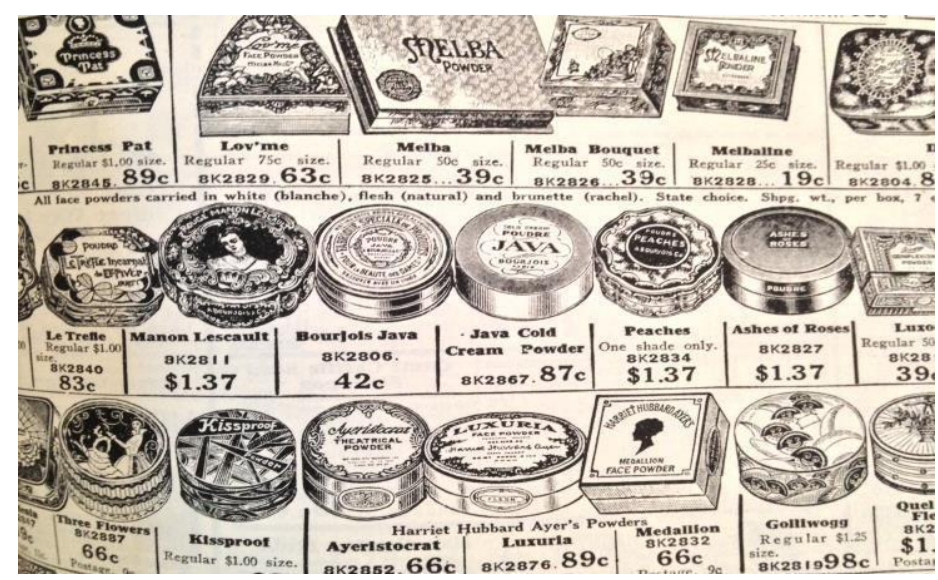

Figure 1h. 1927 Selection of Face Powders for Sale. Most makeup in the 1920s was limited to just a few shades that never matched natural skin tone. The initial look of women in makeup was ghastly! With limited colors, chalky foundations, and no previous generations of women to teach them how to apply makeup, the first attempts were anything but glamorous. Women didn't seem to mind. As the decade progressed, the quality of makeup improved. The number of products went from a few dozen to 450 by 1924 . By the end of the twenties, there were 1300 brands and shades of face powder, 350 rouges, and a hundred red lipsticks. It was a 52 million-dollar industry. Poor women used home remedies such as ivory face powder, although the tanned look was in and many women shunned the pale skin of the past.
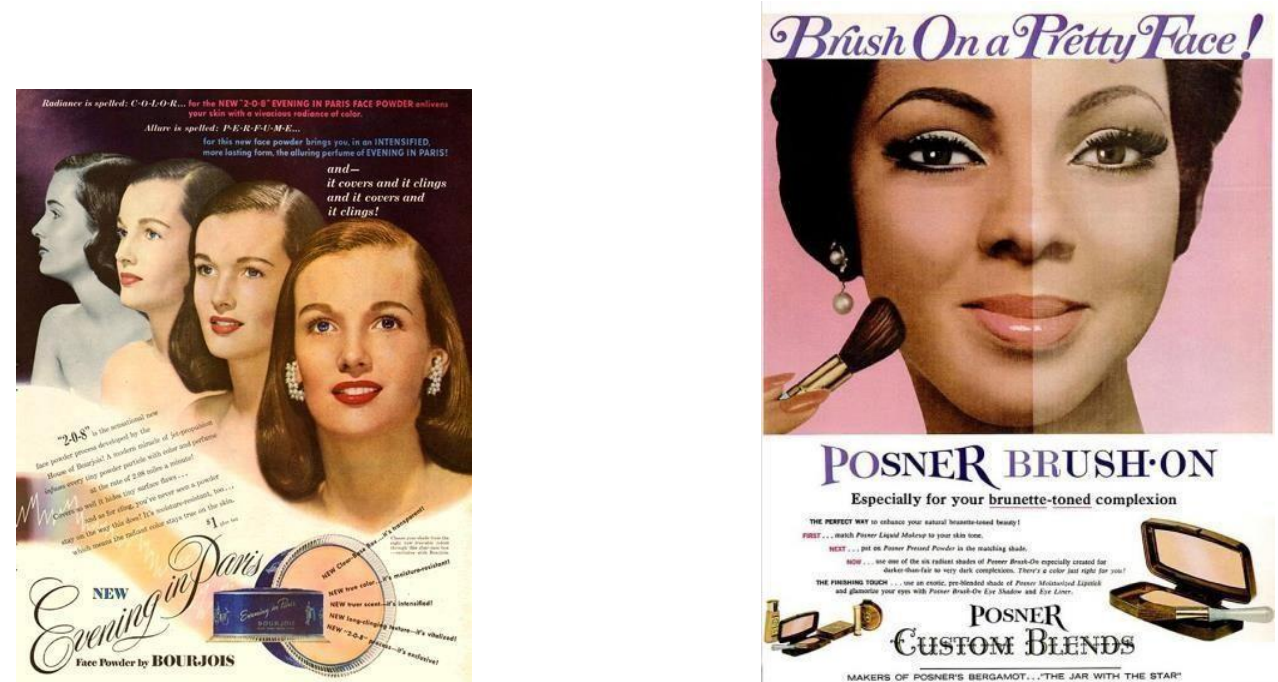

Figure 1i. 1947 Bourjois Face Powder. Part of a matching Figure 1j. 1960s Posner Makeup Ad range of cosmetics all scented with Evening in Paris perfume

Figure 1. Historical Face Powders

\section{Introduction}

Face powders provide coverage of complexion imperfections, oil control, a matte finish, and tactile smoothness to the skin. Powders give a good lasting effect to foundation makeup and possess oil-absorbing properties that are very useful for oily-skin types. Free powders are used to fix the foundation and compact powders to retouch one's face during day. Certain face powders are readily made, but it is not easy to produce a really good face powder, i.e., one that spreads well and smoothly on the skin, has the right matt look and degree of opacity, wears well in hot weather and blustery weather, is available in a variety of color shades, is attractively perfumed; and is at all times uniform and consistent in quality. Face powder is more complicated and made by a mixture of products: Talc and sericite (to help to spread), chalk or kaolin (to give moistureabsorbing qualities), magnesium stearate (gives adherence), zinc oxide and titanium oxide (to help cover the skin thoroughly), and pigments (for color). The use of mica in powder formulations improves skin feel, product application, and skin adhesion. The favorable effects are obtained with wet ground micas that have a particle size of $<15 \mathrm{~mm}$. Mica can also be modified by coating with inorganic or organic materials to produce another large group of fillers (spherical, special, and surface modified). Spherical fillers are widely used to improve skin feel. There are a variety of materials available, the organic types consisting mainly of polyamides, nylon spheres and inorganic types consisting mainly of silica, both as solid or hollow spheres. The improvement of skin feel is attributed to the ball bearing-like action of the spheres between other powder ingredients in the formulation and the spherical filler. When spherical materials are used, there is also an increase in the viscosity of the emulsion, allowing for a reduction of viscosity modifiers in the final formulation. These early commercial face powders were generally simple mixtures of three or more substances. Common ingredients included talc, natural starches like potato and rice, calcium carbonate (chalk), magnesium carbonate, kieselguhr (diatomite), washed china clay (kaolin), bismuth subchloride and subnitrate, zinc and magnesium stearate, ground orris root and zinc oxide. A very important constituent of powder is oxide of zinc, owing to its great covering power, also by reason of its adhesive properties, as an addition to the lighter kinds of starch and also of carbonate of magnesia. 
It forms an important component of all kinds of powders, aside from the fact that from a hygienic point of view it is very desirable. Some of these, such as orris root and bismuth compounds, fell out of favor, while others, like zinc oxide, that were initially treated with suspicion, became staple ingredients. Nowadays, $\mathrm{BiOCl}$ is much more stable to UV light. Special fillers are a group of fillers that are made up of several components, which

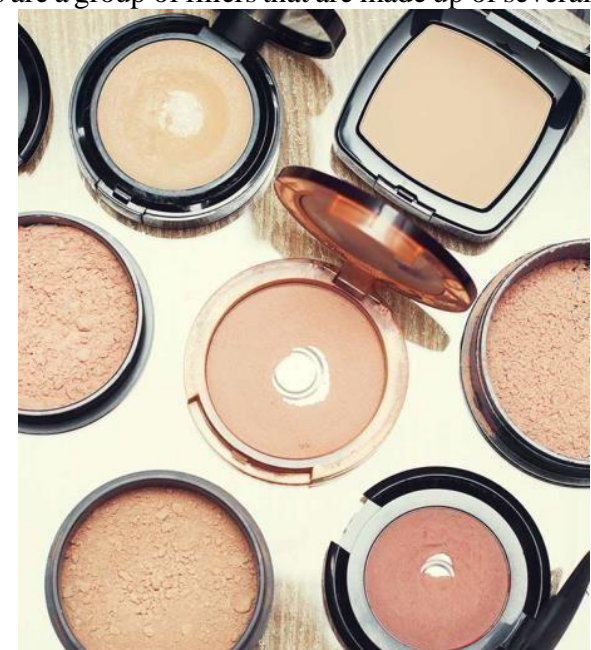

Figure 2a. Compact Collection (Source: Stylecraze) combine their individual advantages when they are processed together into a composite material. For surface-modified fillers, most coating materials are organic polymers (collagen, elastin, and vitamin E). Powders also contain between $10 \%$ and $20 \%$ of organic texture agents (polymers) or mineral agents (boron nitride and silica), preservatives, anti-oxidants, and perfumes (neutral or more sophisticated) can also be added there.

Figure 2. Modern day Face Setting Powders and Compacts

\subsection{Functional use of face powder}

New uses for 'face powders' have been established, such as the correction of heightened color where there is too much red coloration or too much yellow in the case of sallow complexions. The borderline between what constitutes a face powder and a foundation has become very blurred with the development of dual-function products. The main function of early face powders was to visually cover the skin, so that shine was reduced and imperfections were hidden. The amount of concealment needed varied from woman to woman, so powders were produced in various grades loosely referred to as light, medium and heavy. However, the main functional uses are:

- Its prime function goes with the ability to complement skin color by imparting a velvet like finish.

- It is opaque enough to make minor blemishes, masking minor imperfections but it must not impart a mask like effect.

- Whatever the finish it must possess some reasonable lasting properties to avoid need for re-powdering i.e. it must adhere to the skin.

- It must be reasonably resistant to the mixed secretions of the skin.
- Finally, it should serve as a vehicle for pleasing odor to be disseminated by intimate contact of perfume laden particles over a warm and relatively large area.

Also, there are some other interesting uses of face powders such as:

- As an eyeshadow primer: Using an eye primer helps eyeshadow look more vibrant and fresher for longer, powdering eyelids can be emergency solution. Not only will this mattify oily eyelids, it'll also make blending easier since powders blend over other powders better than over bare eyelids.

- As a lipstick mattifier: First thing is to settle a thin layer of tissue on lips, then with a brush, and then taping some loose powder over the area to seal that color in.

- As a mascara primer: In between applying thin layers of mascara, some translucent loose powder over lashes to be brushed before mascara is completely dried.

- As emergency dry shampoo: The majority of dry shampoos consists of highly absorbent powder like ingredients such as starch and clay etc., which acts to soak up the oil and grease at the roots of hair. However, to absorb the bulk of oils, a pre-blot with a piece of tissue or blotting paper is necessary to prevent the powder from clumping up and taping of some colorless loose powder on top of those oily areas afterwards [1-7].

\begin{tabular}{|c|c|c|c|c|c|}
\hline \multicolumn{2}{|c|}{ Fatty powder for rough/dry skin } & \multicolumn{2}{|c|}{ Matt effect or shimmer } & \multicolumn{2}{|l|}{ Make-Up Cream } \\
\hline Ingredients & Parts & Ingredients & $(\%)$ & Ingredients & $(\%)$ \\
\hline Talc & 1000 & Talc & 77 & Glyceryl mono \& di-stearate & 2 \\
\hline Vaseline & 50 & Zn-stearate & 5 & PEG 400 monostearate & 1 \\
\hline White Beeswax & 40 & $\mathrm{ZnO}$ & 2 & Stearic acid & 11.5 \\
\hline Petroleum Jelly & 40 & Kaolin & 5 & Cetyl alcohol & 0.5 \\
\hline Stearin & 20 & Mica & 10 & Isopropyl palmitate & 2 \\
\hline Glyceryl monostearate & 75 & Red Iron Oxide & 0.36 & PG & 12 \\
\hline \multirow[t]{6}{*}{ Water } & 500 & Yellow Iron Oxide & 0.36 & Sorbitol Syrup & 2.5 \\
\hline & & Black Iron Oxide & 0.03 & Preservative & 0.1 \\
\hline & & Perfume & 0.25 & $\mathrm{TiO}_{2}$ & 2.2 \\
\hline & & & & Talc & 8 \\
\hline & & & & Color Pigments & 1 \\
\hline & & & & Water & 57.4 \\
\hline
\end{tabular}


Table 1. Formulation: Face Powder Vs Make-Up Cream

\begin{tabular}{|l|l|l|l|}
\hline Exhibit 1. Powdered Make-up Vs Cream [111] & Powder cons & Cream pros & Cream Cons \\
\hline Powder pros & Pot as long-lasting as powder \\
\hline $\begin{array}{l}\text { Gives a matte, velvety finish to } \\
\text { the skin for an 'airbrush' effect }\end{array}$ & $\begin{array}{l}\text { Can be ageing as it settles into } \\
\text { fine lines and wrinkles }\end{array}$ & $\begin{array}{l}\text { Easy to blend into skin as } \\
\text { they 'melt' into it }\end{array}$ & No brushes are required \\
\hline $\begin{array}{l}\text { Very long-lasting, especially if } \\
\text { applied on top of foundation }\end{array}$ & $\begin{array}{l}\text { Requires brushes generally and } \\
\text { a bit of technique }\end{array}$ & $\begin{array}{l}\text { Tends to crease more easily } \\
\text { (especially on the eyes), can turn } \\
\text { shiny and move around. }\end{array}$ \\
\hline $\begin{array}{l}\text { Helps absorb natural skin oils so } \\
\text { doesn't crease easily, best option } \\
\text { for oily skin }\end{array}$ & $\begin{array}{l}\text { Looks slightly less natural as it } \\
\text { sits on top of skin }\end{array}$ & $\begin{array}{l}\text { Highly pigmented in } \\
\text { general, a small amount } \\
\text { is needed }\end{array}$ & $\begin{array}{l}\text { Not the best option for oily skins } \\
\text { (although matt-finish cream-to- } \\
\text { powder formulas can work well) }\end{array}$ \\
\hline $\begin{array}{l}\text { Can be layered on top of each } \\
\text { other as well as on top of cream } \\
\text { products }\end{array}$ & $\begin{array}{l}\text { Can make skin feel dry or } \\
\text { dehydrated }\end{array}$ & $\begin{array}{l}\text { Good for drier or more } \\
\text { mature skins }\end{array}$ & $\begin{array}{l}\text { Only works on top of other creams, } \\
\text { can't applied on top of powder }\end{array}$ \\
\hline $\begin{array}{l}\text { Blending different powder colors } \\
\text { and textures is easy }\end{array}$ & $\begin{array}{l}\text { Can cause 'powder fallout' } \\
\text { under the eyes and too-matt } \\
\text { powders can make skin look } \\
\text { flat and dull }\end{array}$ & $\begin{array}{l}\text { Leaves skin with a dewy } \\
\text { glow and a hydrated feel }\end{array}$ & $\begin{array}{l}\text { Blending cream colors together not } \\
\text { as easy as powders }\end{array}$ \\
\hline
\end{tabular}

\subsection{Essential Properties of a Good Face Powder}

In recent times the fashion has changed from a 'painted clown' look to one that appears to be as natural as if the skin had no product applied, but without the imperfections. Modern products are also required to be 'longlasting', preferably all day, and consequently avoid repeated application; they should not rub off onto clothing (either that of the wearer or of anybody else).

- Covering Power-ability to mask skin defects such as skin shine, enlarged pores and minor blemishes.

- $\quad$ Slip- faculty of spreading over the skin without dragging and giving the characteristic smooth feeling. There must be sufficient slip to enable the powder to be applied to the skin with a suitable applicator, such as a puff or brush, without dragging or producing a blotchy effect.

- Adhesiveness- ability to cling to the face. It should adhere to the skin and must not be completely dissipated in a short time, so avoiding frequent re-powdering.

- Absorbency-capable of absorbing skin secretions (perspiration and oiliness) without showing evidence of such absorption.

- Bloom-ability to impart a velvety peach like finish to the skin. Shine on or around the nose must be completely eliminated. The powder must be absorbent without changing its appearance on the skin [6-10].

\subsection{Choosing right face powder}

Face powder is hardly exciting, but it can play a big role in adding polish to finished look, not to mention helping makeup last longer. Prior choosing a face powder one should focus the actual need or objective.

- A long-lasting make-up needs improved staying power and it is suggested to look for products labeled as "setting" or "finishing" powders. These all-purpose powders can keep foundation from separating and, to some degree, protect it from the effects of heat and humidity.

- For oily or combination skin, a powder that's described as "mattifying," "oil control," "shine control," or "blotting." Should be considered. A powder with these qualities generally has additional absorbent ingredients to help with oily skin concerns. However, this is not the powder for those with dry to very dry skin because the extra absorbency will likely make dry skin feel tighter and uncomfortable.

- Using powder is still a good idea in case of dry skin because it can keep makeup from creasing. Its best to seek out formulas that go a bit lighter on the absorbent ingredients, like starches and clays. If someone want to enliven dull, dry skin, choose products that have words like "glow," "luminous," or "brightening" in their descriptions. These types generally include mineral pigments that reflect light off the face, and have a softer texture.

- Once the role play of the powder is selected, there are a couple of other factors to consider, which are mainly a matter of personal preference. Tinted powders can enhance the color of foundation, but translucent is the way to go if the color of base makeup is found ok.

- There's also the consideration of pressed or loose powder. Loose powder is easier to pick up on a brush and it's easier to tell how much it's in use, but for touching up on the go, pressed powder is a relatively good option $[3,4]$.

\subsection{Types of Face Powder}

The marketplace offers a profusion of powders. There are two main forms of face powder. Loose face powder comes in a sealed tambourine inside a decorative plastic container. It is either applied directly from this by a puff or large brush, or is transferred to a special compact in which it can be carried in a handbag and is applied with a sponge or small puff that also fits in the compact. To prevent leakage a nylon mesh covers the surface of the powder. In its second form the powder is compacted or pressed and a binding agent is used in its manufacture. There are matte face powders, in loose or pressed form, that are designed for dry, normal or oily skin; translucent powders that allow the natural skin color to show through; opalescent powders that give the skin a slight shimmer; tinted powders that tone down ruddiness; body powders that are suffused with fragrance or with glitter for nighttime sparkle; baby powders that are made from either talc or cornstarch; medicated powders that fight body odor and troublesome microorganisms or soothe irritations, and even perfumed liquid body "coolers" - powder suspended in an alcohol base - that dry on the skin to a powder finish. However, in various books and articles, face powders are classified in the following way:

- Loose Powder: Leaves the skin with a refined texture and soft glow. Loose powder is the original type of face powder. It has light and soft texture. The talc powder makes the formula easily absorbed on the skin and make face free from oil. That is why, loose powder is suitable for oily skin. Typically, loose powder is packaged in a jar equipped with a puff. The disadvantages of this powder are not durable and easily smudged by sweat. It also 
helps to prevent makeup transfer or runoff one may experience in the middle of the day. For people with oily skin, wearing loose powder is a must because it helps to control oil, keeping the face free from shine. Loose powder seals the moist consistency of foundation and makes it last longer.

- Pressed Powder: Compact powder or pressed powder is a loose powder that was compacted. The main difference between loose and pressed powders is the way the product is packaged. Pressed powders are pressed into a compact, loose powders are often packaged in jars or tubs. Typically, compact powder has been formulated with a moisturizer and oil. It makes the texture heavier than loose powder. It also makes face look greasy in 23 hours after wear this powder. Therefore, compact powder is recommended for dry skin. Beside brighten the face, it also moisturizes the skin.

- Two Way Cake Powder: This multitasking pressed powder glides easily over skin to provide a flawless, natural-looking matte finish. The coverage of this powder is very perfect, because it contains a foundation formula. This powder very recommended to cover blemishes, dark spot, with durable results.

- Setting Powder: Designed to "set" or hold foundation in place, setting powders prevent base makeup from rubbing off and reduce shine for a long-lasting, flawless complexion. Available in two common forms - loose and pressed - setting powders can be translucent or slightly tinted to match skin tone. Setting

- powder serves to eliminate oil and keeping makeup to be more durable, and also give it that extra wow factor by combatting shine and maintaining an even, matte finish. Typically, setting powder comes with the type of translucent or transparent powder.

- Finishing powder: It is used to lock the finished makeup. It can be used to maximize the bright makeup that looks uneven, and fading the fine lines or pores in the face. Typically, finishing powder is the white powder. The fine line between finishing powder and setting powder is frustratingly blurry. Most commonly sold in loose form, finishing powders blur fine lines, conceal pores and leave a flawless, camera-ready finish $[8,9]$.

\begin{tabular}{|c|c|c|c|c|}
\hline & \multicolumn{2}{|l|}{ Formula 1} & \multicolumn{2}{|l|}{ Formula 2} \\
\hline & Ingredients & $\%$ & Ingredients & $\%$ \\
\hline \multirow[t]{7}{*}{ Part A } & $\begin{array}{l}\text { Stearic Acid (Triple } \\
\text { Pressed) }\end{array}$ & 1.35 & $\begin{array}{l}\text { Stearic Acid (Triple } \\
\text { Pressed) }\end{array}$ & 3.1 \\
\hline & $\begin{array}{ll}\text { Propylene } & \text { Glycol } \\
\text { Monostearate } & \end{array}$ & 3.95 & $\begin{array}{ll}\text { Propylene } & \text { Glycol } \\
\text { Monostearate } & \end{array}$ & 3.55 \\
\hline & Lanolin & 1.05 & Lanolin & 1 \\
\hline & Mineral Oil 80-90 & 12.2 & Mineral Oil 65-75 & 9.2 \\
\hline & $\begin{array}{ll}\text { Propyl } & p- \\
\text { hydroxybenzoate } & \end{array}$ & 0.05 & $\begin{array}{ll}\text { Propyl } & \text { p- } \\
\text { hydroxybenzoate }\end{array}$ & 0.05 \\
\hline & Amerchol L-101 & 2.65 & Ceraphyl 31 & 4.7 \\
\hline & & & Ceraphyl 140 & 3.1 \\
\hline \multirow[t]{6}{*}{ Part B } & Water & 56.8 & Water & 53 \\
\hline & Triethanolamine & 0.2 & Triethanolamine & 2.15 \\
\hline & Propylene glycol & 5.3 & & \\
\hline & $\mathrm{Na}-\mathrm{CMC}$ & 0.25 & & \\
\hline & Veegum & 1.1 & Veegum & 0.55 \\
\hline & $\begin{array}{l}\text { Methyl } \\
\text { hydroxybenzoate }\end{array}$ & 0.1 & $\begin{array}{l}\text { Methyl } \\
\text { hydroxybenzoate }\end{array}$ & 0.1 \\
\hline \multirow[t]{5}{*}{ Part C } & Titanium dioxide 3328 & 8.3 & Titanium dioxide & 8 \\
\hline & Kaolin Colloidal & 5.1 & Kaolin Colloidal & 4.1 \\
\hline & Na-Lauryl sulfate & 0.8 & Na-Lauryl sulfate & 0.7 \\
\hline & Talc Alabama \#141 & 0.35 & Talc & 1.6 \\
\hline & Iron oxide & 0.45 & & \\
\hline Perfume & & q.s. & & q.s. \\
\hline
\end{tabular}

Table 2. Compact Face Powder

Procedure: Part B is to be heated and agitated at $70^{\circ} \mathrm{C}$. It requires at least 3 hours for the Veegum to absorb all the water. Then balance of $\mathrm{B}$ added and heated to $80^{\circ} \mathrm{C}$. Part $\mathrm{A}$ is to be heated at $75^{\circ} \mathrm{C}$. Then Part $\mathrm{B}$ is to be added to Part $\mathrm{A}$ with rapid agitation. Part $\mathrm{C}$ is to be added at $60^{\circ} \mathrm{C}$. The whole formulation should be passed through colloid mill. The whole mixture is to be agitated until room temperature is reached. Function of Ingredients: In topical formulations, stearic acid is used as an emulsifying and solubilizing agent. It is highly soluble in structurally diverse solvents. Stearic acid is a hard, white or faintly yellow-colored, somewhat glossy, crystalline solid or a white or yellowish white powder. Propylene Glycol Monostearate is a lipophilic emulsifier that is a propylene glycol ester. It is a colorless, viscous liquid. It has a wide range of applications including industrial solvents, paint and coating solvents, polyester and alkyd resins, antifreeze coolants, heat transfer fluids, deicing fluids, plasticizers, detergents and surfactants, and bactericide. USP grade is used in foods, pharmaceutical, and personal care products. Propylene glycol monostearate is not approved in Germany. It is only slightly water dispersible, but completely soluble in fats and oils, therefore it is used only in combination with oils and fats as an emulsifier and emulsion stabilizer. In cosmetic industry it is used as an emulsifier for lotions, soft cream, makeup, humectant in dry skin products. Hydrous lanolin should be stored in a well-filled, well-closed container protected from light, in a cool, dry place. Normal storage life is 2 years. Lanolin is widely used in topical pharmaceutical formulations and cosmetics. Lanolin may be used 
as a hydrophobic vehicle and in the preparation of water-in-oil creams and ointments. When mixed with suitable vegetable oils or with soft paraffin, it produces emollient creams that penetrate the skin and hence facilitate the absorption of drugs. Lanolin mixes with about twice its own weight of water, without separation, to produce stable emulsions that do not readily become rancid on storage. Amerchol L-101 is a mixture of mineral oil and lanolin alcohols. It is an oily liquid used in topical pharmaceutical formulations and cosmetics as an emulsifying agent with emollient properties. A pale yellow-colored, oily liquid with a faint characteristic sterol odor. It is generally regarded as an essentially nontoxic and nonirritant material. However, lanolin alcohols may be irritant to the skin and causes hypersensitivity in some individuals. Veegum ${ }^{\circledR}$ (Magnesium aluminum silicate) is smectite clay that forms a colloidal structure in water that is well suited for suspension stabilization. It exhibits synergistic interaction with thickening agents. It occurs as off-white to creamy white, odorless, tasteless, soft, slippery small flakes, or as a fine, micronized powder. It is used as a stabilizing agent at $0.5 \%$ to $2.5 \%$ concentration and topical suspending agent at $1 \%$ to $10 \%$ concentration. Na- Lauryl sulfate is widely used surfactant in shampoos, bath products, hair colorings, facial makeup, deodorants and perfumes. It is infused into skincare emulsifying products to function as an effective cleansing agent.

\section{Ingredients used in face powders}

The highly purified powders of the present are a far cry from the crude cosmetics of the past. From the dawn of history, vanity led women to sometimes life-threatening lengths to whiten their skin. The earliest powders were concocted from ingredients such as bean flour, chalk and ceruse, a highly toxic white lead. Today, most powders are a blend of several ingredients, including talc, zinc oxide, titanium dioxide, kaolin and magnesium carbonate, each of which imparts specific benefits. Face powder is more complicated and made by a mixture of products: According to cosmetic chemists, the ideal powders should have five characteristics: covering power, absorbency, adhesiveness, slip and bloom. Transparent powders have the same formulation as full-coverage powders except they contain less talc, titanium dioxide, or zinc oxide, since coverage is not a priority. Transparent facial powders commonly have a light shine, produced by nacreous pigments, such as bismuth oxychloride, mica, titanium-dioxide-coated mica, or crystalline calcium carbonate. Facial powder usually uses iron oxides as the main pigment, but other inorganic pigments such as ultramarines, chrome oxide, and chrome hydrate may also be used [10-12].

\subsection{Covering Power}

Covering power is the quality that enables a powder to conceal blemishes, skin imperfections and shine. Ingredients such as titanium dioxide, zinc oxide, kaolin and magnesium oxide are used for their covering power. Titanium dioxide is the most potent covering agent. Zinc oxide is somewhat astringent and antiseptic, and has a soothing effect. It also acts as a sunscreen agent $[13,14]$.

A. Talc: Talc is a kind of soft and smooth stone which is called Katuseki in Japanese. Talc is the sole component of face powders; in some products it could comprise up to $70 \%$ or $75 \%$ of the formulation. Chemically it is a hydrated magnesium silicate with the assigned formula $3 \mathrm{MgO} 2.4 \mathrm{SiO} 2 . \mathrm{H} 2 \mathrm{O}$, and is found in Italy, France, Norway, India, Spain, the USA, Australia, China, Egypt and Japan. Of these the Italian, French, American, Australian and some Indian and Chinese grades can be used for cosmetic powders [12], [15]. Grades of talc should be judged on slip, smoothness, fineness, grit, density, color and odor [16]. In addition, a check should be made for impurities such as carbonates and water-soluble iron and the talc must be free from asbestos impurities, such as actinolite and tremolite, chrysotile and anthophyllite (found responsible for mesothelioma in women) $[17,18]$. The particle size of the talc can significantly affect the appearance and feel of the finished formulation; the smaller the particle sizes the smoother it will feel. However, very fine talc can start to feel gritty. It is also important to note that the finer the talc the opaquer it becomes, and it therefore becomes a question of balance to give the desired feel and opacity [16]. Care must be taken to ensure that the talc has been adequately treated to overcome any possible microbial contamination, the major concern being tetanus spores. In an older study, $17 \%$ of the talc preparations were examined contained coliforms in the range of 230-500 c.f.u./g. Staphylococcus spp., more than $80 \%$ of the talcum powders examined were contaminated with fungi (100 fungal cells/g.) [19]. Talc is used mainly because of outstanding spreadability (slip) and low covering power (translucency) [16]. Talc is not genotoxic. Mechanistic, pathology and animal model studies have not found evidence for a carcinogenic effect except studies reported strong association of epithelial ovarian cancer from perineal talc use [20-25]. Talc is a translucent mineral with a pearly luster. Talc is the softest known mineral and is assigned a hardness of 1 (as compared to a diamond's hardness of 10) on the Mohs Hardness scale. Generally, talc is a semi-free flowing powder, talc smears and tends to fluidize, meaning the fine talc particles take on characteristics of a liquid. Talc powder is best kept as dry as possible. Once it is wet, talc in powder form becomes very slimy and is extremely hard to handle as a heavy precipitate [26].

\begin{tabular}{|l|l|l|l|l|l|l|l|}
\hline $\begin{array}{l}\text { Transparent } \\
\text { Type }\end{array}$ & "Light" & \multicolumn{2}{l|}{ Opaque Matt Finish } & \multicolumn{2}{l|}{$\begin{array}{l}\text { Medium Weight \& } \\
\text { Opacity }\end{array}$} & \multicolumn{2}{l|}{ Other Variation } \\
\hline Ingredient & $\%$ & Ingredient & $\%$ & Ingredient & $\%$ & Ingredient & $\%$ \\
\hline Talc & 80 & Talc & 30 & Talc & 65 & Talc & 50 \\
\hline Zinc Oxide & 5 & Zinc Oxide & 24 & Zinc Oxide & 20 & Zinc Oxide & 15 \\
\hline Zinc Stearate & 5 & Zinc Stearate & 6 & Zinc Stearate & 5 & Zinc Stearate & 5 \\
\hline Rice Starch & 10 & $\begin{array}{l}\text { Precipitated } \\
\text { Chalk }\end{array}$ & 40 & $\begin{array}{l}\text { Precipitated } \\
\text { Chalk }\end{array}$ & 10 & Rice Starch & 15 \\
\hline Perfume & q.s. & Perfume & q.s. & Perfume & q.s. & $\begin{array}{l}\text { Precipitated } \\
\text { Chalk }\end{array}$ & 15 \\
\hline Color & q.s. & Color & q.s. & Color & q.s. & - & - \\
\hline
\end{tabular}

Table 3. Talc-Based Face Powder Formulations 
B. Titanium dioxide: It is naturally opaque and bright, which makes it useful for use in paper, ceramics, rubber, textiles, paints and cosmetics. It is also UV-resistant, and is used widely in sunscreens and pigments that are likely to be exposed to light. It is used in a wide variety of personal care products, including color cosmetics such as eye shadow and blush, loose and pressed powders and in sunscreens [27]. $\mathrm{TiO} 2$ was the first micro-pigment extensively used. Advantages include a broad spectrum of protection and inability to cause contact dermatitis. Particle size and uniformity of dispersion is key to achieving SPF. Primary particle size may be 10 to $15 \mathrm{~nm}$ with secondary particle assembly to $100 \mathrm{~nm}$. Particle size needs to be less than $200 \mathrm{~nm}$ to achieve transparency [28]. Its high technological attractiveness originates from its light-scattering properties and very high refractive index, which mean that relatively low levels of the pigment are required to achieve a white, opaque coating. The range of light that is scattered depends on the particle size. The increasing production of nano-sized $\mathrm{TiO} 2$ powder has led to growing concerns about the consequences of exposure of humans and the environment. The natural opaqueness of these micro-sized sunscreen components is eliminated without reducing their UV blocking efficacy by utilizing nanosized $\mathrm{ZnO}$ and $\mathrm{TiO} 2$ particles [29]. Crystalline $\mathrm{TiO} 2$ occurs naturally in three polymorphs - anatase, rutile and brookite - among which rutile is the most stable [30]. anatase is 100 times more toxic than rutile in the nanoparticular form [31]. Prior to coating, titanium dioxide-rutile pigments that are produced by chlorination contain about $1 \%$ alumina, which is concentrated at the surface of the particles, but not titanium dioxide-anatase [32]. The use of rutile as opposed to anatase crystal forms of $\mathrm{TiO} 2$ lessens photoactivity [30]. Titanium accumulates in the liver, muscle, and brain and decreased muscular AChE activity after acute exposure, showing neurotoxic potential [33]. However, the lack of penetration through the epidermis is also the main reason for the absence of skin carcinogenesispromoting effects $[34,35]$. Its covering power of $\mathrm{TiO} 2$ is 1.6 times more than the $\mathrm{ZnO}$ on dry skin and 2.5 times more on moist and greasy skin [36]. Under similar experimental conditions, presence of $5 \% \mathrm{TiO} 2$ increased the refractive index approximately seven times compared with that of $\mathrm{ZnO}$ alone [29]. Currently, the annual consumption volume of $\mathrm{TiO} 2$ particles reaches four million tons, which makes it the most widely used pigment globally [37].

C. Zinc Oxide: Zinc oxide, with its unique physical and chemical properties, such as high chemical stability, high electrochemical coupling coefficient, broad range of radiation absorption and high photostability, is a multifunctional material. Its low toxicity, biocompatibility and biodegradability make it a material of interest for biomedicine and in pro-ecological systems [38,39]. Zinc also possesses antioxidant property and has been found useful in preventing UV-induced damage and reducing the incidence of malignancies. Its use has also expanded manifold over the years for a number of dermatological conditions including infections (warts, leishmaniasis), inflammatory dermatoses (acne vulgaris, rosacea), pigmentary disorders (melasma), and neoplasias (basal cell carcinoma) [40] and thanks to its non-toxicity, biocompatibility and antimicrobial activity [41]. $\mathrm{ZnO}$ exhibits three crystal structures named wurtzite, zinc-blend, and an occasionally noticed rock-salt [42]. It has been developed in different nanostructures to enhance its interaction with the skin and to improve the existing products. Zinc oxide is the broadest spectrum UVA and UVB reflector approved for use as a sunscreen by the FDA and is allowed in concentrations up to $25 \%$ [43]. Nano-ZnO, due to its extremely small size, gives paper coating pigment a high covering power apart from antifungal and UV-protecting properties [44]. It helps with skin repair by keeping the area surrounding the wound moist and clean and supplying the added zinc that the skin needs to facilitate repair. Additionally, $\mathrm{ZnO}$ increases collagen degradation in necrotic wounds [45]. It works as a skin astringent that prevents oil formation on the surface of the skin. It is a substance that effectively works in drying excess oil in skin [46]. Unlike chemical sunscreens that can cause hormonal disturbance, using products with zinc oxide as one of the main ingredients are a great choice even for those with sensitive skin. Only nanosized $\mathrm{ZnO}$ was able to reach into the deep layers of the allergic skin, but bulk-sized $\mathrm{ZnO}$ stayed in the upper layers of both damaged and allergic skin [47]. If zinc oxide nanoparticles produce ROS, they can damage the skin and cannot be used as sunscreen. The efficiency of zinc oxide nanoparticles depends mainly on the medium of reaction to form $\mathrm{Zn2}+$ and their penetration into the cell [48].

D. Kaolin: Natural clays have been used to heal skin infections since the earliest recorded history. The high adsorption and absorption capacities, cation exchange capacity, as well as the extremely fine particle size of certain clays, e.g. smectites (expandable clay minerals) and kaolin group minerals are important reasons why these minerals are used to remove oils, secretions, toxins, and contaminants from the skin. By adsorbing and absorbing moisture and impurities from the skin, the clays also serve to cleanse and refresh the skin surface and to aid in the healing of topical blemishes, the major selling point for many cosmetics [49]. Kaolin (a hydrated aluminum silicate clay mineral) is a mixture consisting principally of the mineral kaolinite and containing varying amounts of other minerals such as muscovite, quartz, feldspar, and anatase [50]. It is prepared for pharmaceutical and medicinal purposes by levigating with water to remove sand and other impurities. The name is derived from Kao-ling (Chinese: "high ridge", a hill in China from where this clay was first obtained or mined). In general, clay minerals naturally possess various morphologies, including fiber, sheets, scrolls, rods, and tubes [51]. The morphological diversity is created in the process of the formation of clay minerals in nature. Kaolinite is one of the most common clay minerals in the earth's crust and the most widespread phase among the other kaolin polymorphs (halloysite, dickite and nacrite) [52]. The most important functionalities of kaolin used as excipient are reported as diluent, binder, disintegrant, pelletizing and granulating, amorphizing, particle film coating, emulsifying and suspending agent [53]. Because of its uninjured bioactivity, kaolinite has been also used as active agent for treatment of some common diseases. It can be topically administered as hemostatic agent, dermatological protector, anti-inflammatory agent and in pelotherapy, or orally as gastrointestinal protector, and antibacterial, antiviral, detoxification or antidiarrheal agent [54,55]. Red kaolin is considerably more absorbent than other kaolin clays and is thus better suited to acne-prone or oily skin [56]. Even though Kaolin clay is not a great absorbent like other clays, especially bentonite clay, it can remove excess sebum from face. Kaolin clay is white and has a very soft texture. Although it is usually white, it may also come in different colors (mainly pinkish and greenish), depending on the type of other minerals present in that clay. The whiter the clay, the purer and better it is, suited for people with dry, sensitive, and mature skin. It is a natural detoxifier and exfoliator, tones skin and used with green tea, avocado, honey, witch hazel and apple cider vinegar as face mask [57]. Kaolin pneumoconiosis is generally regarded as an inhalational pneumoconiosis. However, on rare occasions 
kaolin may incite lung damage by the mechanism described above [58].

E. Bentonite: For a long time, bentonite has been used externally on skin. It could act as a barrier for toxic organo-phosphorous compound transfer across the skin, which suggests its physical protective action on skin [59]. Bentonite was effective on the improvement of diaper rash, and also had faster effects compared with Calendula [60]. There are different types of bentonite clay; each one is named after the dominant element in the clay, such as potassium, sodium, calcium, magnesium or aluminum. It is a powerful healing clay, is composed of volcanic ash, with a high percentage of montmorillonite, a group of soft minerals. The presence of iron and magnesium ions give Bentonite Clay a subtle greenish-grey color. When mixed with water, bentonite swells up like a sponge and becomes very slippery and almost gel-like [61]. Bentonite is a highly absorbent clay that pulls oils and toxins from the skin. Using a clay face mask can help remove impurities from the skin to treat acne or reduce the risk of pimples and skin infections [62]. Long-term occupational exposures to bentonite dust may cause structural and functional damage to the lungs [63] and systemic exposure may be detrimental to bones because aluminum competes with calcium for absorption [64]. Although, quaternium-18 bentonite presented no evidence of systemic toxicity [65]. Effectiveness of iron-rich clays for healing severe skin infections has recently been documented, drawing attention from the medical community [66]. Once the clay combines with water (perspiration) it gets to work, purifying and removing toxins [67]. Applying a lotion or cream with bentonite clay in it creates a barrier between skin and possible irritants. Bentonite clay also helps skincare products adhere to your skin and be more water resistant [68]. Colloidal clays, either natural processed bentonites or synthetic clays, have been used as binding agents because of their thixotropic properties. Most often, bentonite suspensions are also thixotropic, although rare cases of rheopectic behavior have also been reported [69]. The stabilization of emulsions using powders is not particularly common in cosmetic products, although powders such as veegum and bentonite are sometimes used [70-72].

\subsection{Absorbency}

Powders should have ability to eliminate shiny skin in certain facial areas by absorbing sebaceous secretions and perspiration. Materials for this purpose should have a high absorptive capacity, but at the same time should not change the appearance of the powder on the skin [73]. There are several components of face powder which have this absorptive property such as kaolin, starch, microcrystalline cellulose, magnesium and calcium carbonate. $\mathrm{ZnO}$ and $\mathrm{TiO} 2$ are better in masking skin greasiness but chalk powder, kaolin and starch have better moisture absorption capacity.

A. Starch: Among all-natural available biopolymers, starch is the most commonly applied in the biomaterial fields due to its beneficial advantages such as low-cost, low-toxicity, biodegradability, and renewability. Despite these properties of starch materials, the industrial applications of starch are often limited because of its poor rheological properties and limited surface areas $[74,75]$. Soybean oil, corn flour, and potato starch are common ingredients in moisturizers, masks, and makeup. Corn starch is used as a thickener in cosmetic products, and more recently as a replacement for talc in natural baby powders [76]. Corn meal, or corn flour, is a cheap facial exfoliator that can be safely used in homemade cosmetic preparations. These are often used in face powders. In particular rice starch was very common as a basic ingredient in formulations. It was considered to give a 'peach-like' bloom to the face $[77,78]$. Because the particles are spherical it gives a very smooth feel when applied to the skin. It has excellent absorptive properties and in addition has good covering power. In the presence of water, it tends to cake, and cling to facial hair, giving an unpleasant appearance. It can also become sticky. Starch is synthesized in amyloplasts or chloroplasts, consists of amylose and amylopectin, and exists as semi-crystalline granules in plants [79]. Corn starch exists in two forms, amylose and amylopectin, containing glucose units connected linearly in chains of different lengths and, in amylopectin, with substantial branching. Wheat starch granules have a bimodal size distribution due to initiation of granule growth at different times. Rice starch granules, on average, are the smallest of the commercial starches $(2-9 \mu \mathrm{m})$ [80,81]. Starch can be used as thickener, an adhesive, binder, encapsulating agent, film former, gelling agent, water binder, texturizer and fat-sparing agent and with numerous other applications. Starch can be modified by acid hydrolysis, oxidation, etherification, esterification and cross-linking. Various methods such as acid, phosphate and $\mathrm{H}_{2} \mathrm{O}_{2}$ treatments can be employed to modify starch [82]. Modified starches are now available which can be very beneficial in powder products. Modification of starch led to new products with new desirable properties. Corn starch samples modified by acid hydrolysis combined with heat moisture treatment were made by changing $\mathrm{pH}$, moisture content and treated temperature. After modification, swelling power at temperature higher than $75^{\circ} \mathrm{C}$ of corn starches decreased while solubility of the starches increased [83]. They can be used as talc replacements in some products. Unfortunately, both starches and modified starches are ideal media for microbiological growth; it is therefore important that the grades used are sterilized prior to use, that the manufacturing environment is as clean as possible to prevent contamination and that sufficient preservatives are used in the formulation. Silver-starch nanocomposite material $[\operatorname{AgNPs}(<10 \mathrm{~nm})]$ can be successfully employed to prevent the viability and growth of the common pathogens Staphylococcus aureus, Escherichia coli and Candida albicans [84].

B. Calcium carbonate (Chalk Powder): Calcium carbonate occurs as an odorless and tasteless white powder or crystals. Calcium carbonates are one of the most abundant minerals in the earth's crust. It is obtained from the naturally occurring minerals aragonite, calcite, and vaterite. They occur in the form of limestone and chalk, formed from fossils, and marble, formed from the metamorphosis of sedimentary rock. They consist mostly (>98\%) of $\mathrm{CaCO}_{3}$, with trace amounts of magnesium carbonate, iron oxide, and aluminum silicates [78], [85]. It is mainly used in oral pharmaceutical formulations and is generally regarded as a nontoxic material. Calcium carbonate may be irritant to the eyes and on inhalation. Particle size is important and, for some applications requiring good weathering and impact performance (window profile), the ultrafine milled, high whiteness, natural version is normally used. Ground and precipitated calcium carbonate is used as an ingredient in the formulation of personal care products, cosmetics and toiletries. In make-up products, it is taken into use as a pigment extender, prolonger, whitener and oil absorber. Because calcium carbonate absorbs moisture it is frequently used as an ingredient in face powders to upsurge the capacity of the makeup to engross moisture and it makes a good absorber in primers, foundations, and finishing powders. It is known in the cosmeticindustry for its absorbent power, translucency, opacity, skin protecting properties, adhesion power that makes make-up to stay for long on the body, and light scattering properties [86]. The brightness and opacity of the calcium carbonates make them suitable for use in white and color cosmetics. They can even be considered as an extender of titanium dioxide and act as a natural source of calcium. To meet the brightness, polishing and opacifying requirements of the cosmetic industry, the calcium carbonates are available as limestone and marble-based products. While marble-based calcium carbonate 
exhibits high brightness, low oil absorption and low yellow index, limestone calcium carbonate exhibits homogenous deposit, high brightness, higher yellow index and improved opacity [87]. A grit free precipitate chalk or calcium carbonate is mildly alkaline, white, odorless, microcrystalline powder and it reduces the shine of talc and has a good covering power, it helps to absorb the perfume and is also grease resistant and perspiration absorbent. If this raw material is used in excess, the powder may acquire a dry feel, but moderate usage is most helpful to face powder formulas. In face powder formulations, chalk powder preserves certain balance between slip and adhesion, coverage power and transparency and develop "bloom effect" when face powder is applied [88]. Given that a variety of bacterial species may occur in the calcium carbonate powder used for cosmetic formulations, an understanding of their diversity and abundance is necessary to accurately assess the contamination of the finished product [89].

C. Magnesium Carbonate: Basic magnesium carbonate comprising a tubular aggregated particle of flaky fine crystals, having characteristics that a bulk density is as low as 0.2 to $0.3 \mathrm{~g} / \mathrm{mL}$, and a specific surface area is comparatively high and is 10 to $40 \mathrm{~m} 2 / \mathrm{g}$. There are two main branches of sedimentary petrology. One branch deal with carbonate rocks, namely limestones and dolomites, composed principally of calcium carbonate (calcite) and calcium magnesium carbonate (dolomite) [90]. $\mathrm{MgCO}_{3}$ is used as an absorbent, opacifying agent, coloring agent, or to adjust the $\mathrm{pH}$ of cosmetic products. It is white, tasteless, odorless, amorphous, fine powder. It is used as an anticaking agent in free flow table salts due to its high hygroscopicity [91]. It is used in cosmetic industries especially in talcum powder, face powder, body powder, etc. Due to its marked absorptive powder it is incorporated in special soaps. The white powder is used in pharmaceutical preparations, hair bleach, powdered shampoo, cosmetic powder formulations, foot care and skin care. Among others, it is ideal as an absorbent/binder, bulking agent, and opacifier [92]. In the presence of dry skin, oil-absorbing products such as powders should be avoided. If a powder is desired, it should be low in magnesium carbonate and zinc oxide, since these two substances have an astringent or drying effect on the face [88]. It decreases the static friction coefficient and imparts fluffiness to the powder [78]. Magnesium protects the skin from free radical damage, inflammation, and it's necessary for the enzymes that regulate cell turnover and repair. A lot of people end up using it topically for the treatment of acne and acne rosacea. Magnesium carbonate cosmetic grade is packed with utmost care in order to prevent moisture absorption by the material due to its hygroscopic property. It has tremendous capacity to absorb oil from skin, prevents formulations from lump formation and acts as a fragrance enhancer. For this reason-often fragrance is added to magnesium carbonate as a separate step during formulation [93].

D. Avicel®/ Microcrystalline cellulose (MCC): Because of its convenience of use, excellent toxicity profile and wide compatibility, Avicel ${ }^{\circledR}$ can be readily incorporated into a wide range of cosmetic formulations. It has use in cosmetics as an abrasive, absorbent, anticaking agent, aqueous viscosity increasing agent, binder, bulking agent, emulsion stabilizer, slip modifier, and texturizer, which can be found in various hair and skin care products as well as makeup. It was discovered in 1955 by Battista and Smith and was first commercialized under the brand name Avicel® [94]. A purified, partially depolymerized alpha-cellulose made by acid hydrolysis of specialty wood pulp [95]. The physical network of insoluble particles formed by Avicel ${ }^{\circledR}$ is pseudoplastic, highly shear-thinning and thixotropic, making it ideal for suspensions, sprayable products and emulsions. These microcrystals, which are insoluble, rod-shaped particles of less than 1 micron in length, can be dried to form commercial products known collectively as non-colloidal grades. During the drying process, hydrogen bonding causes the cellulose microcrystals to form larger, tightly-bound particles that cannot be redisposed later to recover the individual microcrystals [96]. It can be obtained from other sources like from other sources such as newsprint waste, corncobs, bagasse, rice straw as well as fastgrowing plants including Sesbania sesban, Pinus roxburghii and Crotalaria juncea [97]. It is generally considered as the diluent having the best binding properties. It is a white fine crystalline powder, odorless and tasteless, made from free-flowing non-fibrous particles and compressed by its self-adhesion effects [98]. MCC produced from rice husk and cotton are the densest and least porous materials having the fastest flow and lowest compressibility. In contrast, MCC as obtained from bagasse was the least dense and the most porous material and it was as compressible as Avicel® products rendering compacts of good strength [99]. It can be rapidly dispersed in water into the formulation, but insoluble in water, dilute acid or alkali solution, solution and most organic solvents, and can absorb water to swell [100-102]. The large particle size grades of MCCAvicel® PH 102, PH 302 and Pharmacel 102 were found to possess smaller quantities of structured water [103].

\subsection{Slip}

Easy powder flow ability and spread ability are two important parameters that are always considered at the time of manufacturing and evaluation of topical powder. Slip is the property that enables a powder to be easily and smoothly applied without any feeling of drag. As a property slip is hard to define in any quantifiable fashion but like powder grittiness it can be felt with the fingers or on the face. While a number of ingredients can contribute to giving a powder slip - such as the kaolin, the stearates and starch - by far the most important substance is talc (magnesium silicate) which is why it made up to $50 \%$ or more of some face powders. Talc is produced by different countries but Italian, French and some Indian varieties are of very good quality and most suitable for powders specifically face powders. It combines high spreadability (slip) with low translucency and covering power and feels smooth on the skin. kaolin improves homogeneity during spreading, impart good coverage and bring consistency to the formulation. Alurninium hydrosilicate is a valuable basic material for powders It is smooth and fatty. It should be prepared properly by treating with acid, washing with water and then dried. It also has certain cooling effect. It absorbs fatty secretions and small amounts of water. It is completely non-toxic. Other substances used for softness and slip are zinc stearate, magnesium stearate, zinc undecanate, magnesium undecanate. The undecanates, in particular, are soft and have excellent slip but are expensive. properly purified stearates are extensively used [36]. Tapioca starch is particularly useful as it gives a very smooth feel to the product. Due to the chemically inert nature of talc and kaolin, they are the most commonly used ingredients in the formulation of dusting powder [104]. The presence of powders formed by spherical particles in formula allows an excellent spreadability increasing the duration and decreasing the transferability of the make-up. The particle size of the talc can significantly affect the appearance and feel of the finished formulation; the smaller the particle sizes the smoother it will feel. However, very fine talc can start to feel gritty. It is also important to note that the finer the talc the opaquer it becomes, and it therefore becomes a question of balance to give the desired feel and opacity. In terms of extrinsic properties, it is well accepted that spherical powder particles positively contribute towards powder flowability and higher particle packing densities in the powder bed. Spherical morphologies are also typically associated with low levels of particle-particle friction which results in enhanced powder flow [105]. Micronized plastics such as polythene, polystyrene and nylon, not only exhibit good powder but also excellent thermal properties. They can impart a very smooth feel to formulas [106]. These particles are usually spherical and the ball-bearing effect comes into play. Typically, these can be used at between $5 \%$ and $10 \%$ but they are expensive so their use is somewhat limited. Spherical powders such as nylon, silica or polymethyl methacrylate contribute to two-way foundations by giving a silky-smooth feel, enhanced pay-off, and smoother skin application. Some, such as 
silica, act to absorb sebum and perspiration, therefore giving a uniform finish throughout the day. They can also act as light diffusers, minimizing the appearance of pores. The ideal level of spherical powders in two-way foundations generally ranges from $10 \%$ to $13 \%$. However, if the formulation also contains microfine titanium dioxide or zinc oxide, for their sunscreen properties, the level of the spherical powders is usually increased to between $16 \%$ and $18 \%$, to compensate for the coarse feel of the microfine pigments. Increasing the level of spherical powders used results in greater slip, but at the expense of creaminess. Excessive amounts of spherical powders can lead to unstable pressed cakes and to break-up of the cake during use. The silicas, in addition to the silicates, are useful in maintaining the free-flowing properties of powders in high humidity [12].

\subsection{Adhesion}

Adhesive improves the consistency of face powders, ensuring a smooth application. The staying power of a face powder, its ability to stick to the skin, is referred to by cosmetic chemists as its adhesiveness. Lack of adhesion was a common problem with early face powders and many women resorted to using a vanishing or cold cream before powdering to help their face powder stay in place. Known for its smoothing effects and adhesive texture, dimethicone is used in powders to enhance makeup wear and give the skin an airbrushed finish. Also, talc inclusion in a face powder increases its adhesiveness to the skin and avoids the powder dissipating in a short period of time. Cocoa seed butter imparts silky texture on the skin, delivering superior adhesion whether worn on a bare face or with a full beat. Zinc oxide possesses moderate adhesive properties and is comparatively inert [39]. The materials primarily used for imparting adhesive characters are metal soaps primarily zinc stearate and magnesium stearate talc, magnesium and calcium salts of myristic acid. Magnesium stearate has better adhesive property than zinc stearate and is more preferred in face powders. But zinc stearate is more predominantly used in talcum powders. Super quality magnesium and zinc stearates are available with excellent color, texture and minimum of odor. They also give a velvety softness to the product. As they are waterproof, they maintain the complexion intact in inclement weather. Magnesium stearate is used $3-10 \%$ in face powders and any other pharmaceutical powders. Magnesium stearate is permitted for use in the European Union and other countries including China, Japan, Australia and New Zealand, and was granted generally recognized as safe (GRAS) status in the US [107]. Stearates of lithium and calcium are also available for use for the same purpose. Lithium stearate in particular, has also got good covering properties and fluffy texture. Magnesium and calcium salts of myristic acid are also used for their adhesion properties. Magnesium myristate has better adhesion character and a better texture. Cosmetic quality talc, which is a purified hydrated magnesium silicate has adhesion properties. Though it is available in various countries, Italian product is the best and used for face powders. Titanium dioxide is three to four times better as a covering agent than zinc oxide, but it has less adhesion and does not blend quite as well. For a face powder in which an appreciable quantity of covering power is desirable, the judicious use of $\mathrm{TiO} 2$ or $\mathrm{ZnO}$ or a blend of the two is necessary [16]. The adhesion character of the powders can be increased by incorporating $1-2 \%$ of cetyl alcohol, stearyl alcohol, glyceryl monostearate, petrolatum, lanolin or similar fats.

\subsection{Bloom}

Opalescent, or pearly finish, products contain ingredients such as bismuth oxychloride that give them a shimmery glow. The materials chiefly used to impart bloom are chalk, rice starch and prepared starch. Silk Powder is produced from high quality silk using sophisticated technology in order to retain its chemical properties, and is made up of $100 \%$ fibroin, which contains 18 kinds of amino acids and trace elements essential to the human body. It serves as an ideal protein enricher for high quality cosmetics. It is in the form of a yellow powder of 200 mesh diameter that can be applied to a wide range of cosmetics. Users can expect it to help maintain moisture levels in the skin and prevent dryness. Superfine Silk Powder is valued as a filler in mineral makeup formulations to help soften the appearance of fine lines, provide moisture balance, absorb excess oil and provide a silky slip [108]. In addition to being a great filler base for mineral makeup, Superfine Silk Powder can also be used in any type of powdered formulations where oil absorption and a silky slip are desired. It is an exceptional alternative to talc in body and face powders. It helps decrease reflective light from the skins surface creating a soft glow. The fine particle size makes it easy to incorporate into cosmetic formulations. Sericin, which is a protein synthesized by the domestic silkworm, Bombyx mori, is one of these substances. Sericin becomes gel by itself, and forms a film when combined with some polymers by cross-linking and therefore can be used in manufacturing cosmetics and pharmaceuticals [109]. Also known as synthetic pearl, it's the primary ingredient included in most powders that are referred to as "mineral makeup." Some cosmetic companies claim that bismuth oxychloride is natural and better for skin than talc. The truth is that in many ways' talc is a more natural, unadulterated, pure ingredient than bismuth oxychloride. Bismuth oxychloride, an insoluble inorganic pigment which seldom occurs in nature, is used in cosmetics because it has a distinct shimmery, pearlescent appearance and a fine white powder texture that adheres well to skin. However, it is heavier than talc. Far from natural, it was designed to be a replacement for talc. Among its boasted beneficial properties are its great slip and its sheen that offers the wearer a dewy look. It was permanently listed by the FDA as a coloring agent in 1977 and for use as a synthetic ingredient. Women have been advised to scan makeup labels for bismuth oxychloride, the ingredient that gives makeup its pearly finish. It can cause skin irritation and acne flare-ups [110]. Because of its molecular crystalline shape, many individuals experience itching from bismuth oxychloride, which worsens when they sweat.

\subsection{Colors}

The colors used in face powders came mainly from two sources: inorganic pigments like iron oxides (ochres, sienna and umbers) and organic lakes and toners; both types being increasingly controlled by legislation. Inorganic pigments were originally sourced from nature but synthetic forms were later preferred. Synthetics were less likely to have contaminants, were free from grit, more uniform in color from batch to batch and, being purer, had a greater strength of color than their natural counterparts. Inorganic pigments were very stable and had an indefinite shelf life but lacked a certain brilliance so, despite being less stable when exposed to light, organic lakes were often included into face powders as well. Any lake color selected needed to be tested for stability and checked to ensure that it did not readily dissolve in water or oil, otherwise the color would bleed in areas where perspiration or sebum was present. Even if no bleeding occurred, sebum could still have an adverse effect on a powder. Many face powders turned darker and yellower, or darker and redder after they had been on the skin for a while, a problem exacerbated by the fact that color changes were greater where more sebum was produced making an evenly applied face powder look blotchy after a while. Various synthetic or natural inorganic pigments used are iron oxides for yellows, reds, and browns and ultramarine for green and blue [112]. Toxic lead and arsenic compounds are not used. Organic lakes and pigments produce better brilliance but should be selected from certified dyes. The organic pigments must not bleed in oil or water and should be light-fast. Choice of color is mainly users' taste. Various colors with various shades are used to fulfil the satisfaction of the users. The color of the thin film of the pigment may be different from the color effect given by the powder viewed in bulk [113]. Since the ingredients in the base were white or offwhite, they would also affect the powder shade. Consequently, if a manufacturer was making up powders in light, medium and heavy grades, the colors used in each would need to be adjusted to compensate for the varying levels of titanium dioxide and/or zinc oxide used in the different grades to ensure that all were the same shade. As well as the inorganic pigments and lakes other coloring agents have been added to face powders over the years. These include metallic powders (mica, aluminum, bronze) 
to give gold, silver and other metal effects; synthetic bismuth oxychloride and synthetic pearl pigments to give the powder a pearlescent sheen; and various forms of resins and plastics [114]. Women expected their powder shades to remain the same batch after batch and would change brands if they found too much fluctuation from one purchase to another. In the past the colors were checked by eye using samples taken during the milling process which were compared to a reference powder kept on file. The introduction of color measurement by colorimeter greatly improved the accuracy of this procedure. The secret to producing powders of a consistent color was standardization. Standardization of raw materials, proportions, moisture content manufacturing, storage and packaging was the only way to produce consistent results.

\subsection{Perfumes}

From the Renaissance into the nineteenth century, perfume wearing and perfume type were ungendered, and men and women adorned them equally. Sweet floral blends were deemed exclusively feminine, while sharper, woodsy, pine, and cedar notes were characterized as masculine [115]. However, perfume is an essential component of powders. Users put more importance to perfume. But it should not be over emphasized at the time of manufacturing. Normally the products are perfumed lightly, particularly face powders and compacts. The odor must be fragrant and pleasant. An attractive scent was essential if a powder was to enjoy good sales. This enabled the scent in the powder to work with the woman's perfume rather than against it. Care had to be taken when selecting a perfume as the powder base could modify the perfume's odor, making it smell musty. In addition, the scent could also discolor the powder and darken the shade. Various perfumes or fragrance which are used, either flowery fragrance or synthetic odor. Selection of proper fragrance is very vital for the products. Sometime combination of fragrances gives a better appeal [116]. Compatibility of perfume with other constituents of the formulation is to be checked properly before use. Constituents of powder preparation may change the character of fragrance. The addition of a perfume to a powder generally required the powder to be matured or aged for up to a month before it was packaged and sold. Depending on the manufacturing process, ageing could be done before or after the powder was made. If the perfume was mixed into a portion of the powder, e.g. the kaolin, it would be stored and matured before being incorporated into the rest of the powder mix; if it was sprayed on to the powder during the mixing process then the entire powder mixture would be aged before it was packaged.

\section{Evaluation of Powders}

There are various methods available to measure the powder flow. The compendial methods include measurement of angle of repose, bulk density, tapped density, Carr's compressibility index or Hausner ratio. With technological advances, innovative methods of characterization of powder flow such as cohesivity determination, avalanching determination, shear cell, dielectric imaging, atomic force microscopy, penetrometry. These methods suffer from various limitations including reproducibility, performance conditions, and predictability [117]. General tests include determination of contents in the formulation along with the stability test. This is carried out to know whether the product remains stable for prolonged period of time (i.e. shelf life). Other tests are also carried out. They are:

(a) Shade Test: In this test, the variations of color shade are determined and controlled. It is carried out by spreading the powder sample on a white paper and appearance is observed which is compared with the standard one. Another method involves, applying powder sample and standard one with the help of puff on the skin and then comparing it. The puff used to perform this test is also used for the final product. Evaluation of color is carried out by using artificial light.

(b) Color Dispersion Test: in this test, a sample of powder is spread on a white paper and with the help of magnifying glass., segregation or bleeding of the color is observed. the color should be properly distributed in the powder base of the formulation.

(c) Pay-off Test: This test is carried out to check the adhesive property of powders with the puff. This test is mainly carried out on compact powders.

(d) Pressure Test: For compaction purpose in compact powders, pressure required. Uniform pressure should be applied to avoid formation of air pockets, which will lead to either breaking or cracking of compact powders. This is because low pressure will make the compact powder soft, whereas high pressure will lead to formation of hard cake. With the help of penetrometer, uniformity of hardness of the cake is checked. This is done by taking the reading at different points on compact powder and then comparing them.

(e) Breakage Test: In this test, compact powders are allowed to fall on a wooden surface from a height of about 8-10 inches. This is carried out several times and then checking is done to see whether any breakage has occurred on compact powder. If the compact powder remains unbroken, then it shows the resistance to travel and normal handling by the users.

(f) Flow Property Test: This test is carried out maim \} on body powders to determine their flow property (from the container upon usage). This intern helps in easy application of powder to skin. In this method, angle of repose of powder is measured by allowing the powder product to fall on a plate through a funnel. Then the height and the radius of heap formed is measured, and even the time taken for the powder to fall is noted.

(g) Particle Size Determination: With the help of microscope, sieve analysis or by utilizing other techniques and instrument, particle size of powder product is determined.

(h) Abrasive Character: Abrasive character of powder can be determined by, rubbing, the powder on a smooth surface of the skin. Then with the help of a microscope, the effects of powder are studied.

(i) Moisture Content: Moisture content present in the powder can be determined by using following formula. This is usually carried out by using various suitable analytical methods. These methods are also suitable for determining limits for color.

\section{Moisture Content $\%=$ Weight of water in sample $\times 5$} Weight of Dry sample

\section{Regulatory Requirements}

\subsection{REACH/MSDS}

All cosmetic ingredients, including those which are specifically used in cosmetic powders, have to fulfill REACH requirements as individual chemicals. REACH governs the registration, evaluation, authorization and restriction of chemicals in the European Union. Its purpose is to ensure a high level of protection of human health and the environment, the promotion of alternative methods for the assessment of hazards of substances and the free circulation of substances in the internal market while enhancing competitiveness and innovation. Data of such tests and any classification according to GHS/CLP (Globally Harmonized System) which has been implemented in the EU in form of the Regulation (EC) No 1272/2008 on the classification, labeling and packaging of substances and mixtures - CLP Regulation) will be available via the material safety data sheet (MSDS). Each individual hazard classification needs to be considered in the safety assessment of the cosmetic ingredients $[119,120]$.

\subsection{Occupational Exposure Limits}

Apart from chemical substance-specific regulations via REACH or product type specific regulations like the Cosmetics Regulation, occupational exposure limits (OEL) are defined for certain ingredients. As the above introduced occupational exposure scenario for solid particles (dust) is quite different and conservative compared to the typical consumer exposure during the typical use of cosmetic products like loose 
powders, OELs may serve as a first rough estimate for consumer exposure or professional use in a hairdresser salon in safety assessments of powder products [121].

\subsection{Cosmetic Use}

In contrast to the occupational scenario the intentional application of cosmetic products is quite different as both the exposure duration as well as the typical quantities of airborne particles is less prominent. Furthermore, the toxic potential of the ingredients used is significantly lower compared to general industrial chemicals, as all of them have to be approved as safe for the use in such consumer products. However, there are special restrictions for the UV filters titanium dioxide and zinc oxide if the materials contain particles in the nano-size range; as listed in Annex VI entry 27a and 30a (list of UV filters allowed in cosmetic products) as usage restriction of: "Not to be used in applications that may lead to exposure of the end-user's lungs by inhalation". As in the EU, the US FDA requires cosmetic products to be safe without setting specific requirements as to how such safety, specifically of powders, has to be assessed. Cosmetic products and ingredients are not subject to the US FDA pre-market approval authority, with the exception of color additives. The US FDA lays the responsibility on the cosmetic firms for checking the safety of their products and ingredients before introducing them into the market. Regarding $\mathrm{Cu}, \mathrm{Zn}$ and Fe, there is no regulation of the levels in lipsticks or powders. There is only consideration about the metals' uses and restrictions. US Regulations such as Proposition 65 in California have ingredient specific restrictions similar to those of the EU Cosmetic Regulation. Ingredients deemed to be of concern due to inhalation, e.g. titanium dioxide commonly used as a colorant or pearl in powdered cosmetics, have considerations, which must be met to ensure their safety when typically used in consumer products. The ingredient is assessed as 'of concern' if meets three criteria: being unbound, airborne and of respirable size. These criteria were used in several safety evaluations applying the particle size of $10 \mu \mathrm{m}$ as the cut-off for the respirable fraction of airborne particles [122-126].

\section{Epilogue}

Face powder is an indispensable article of a lady's cosmetic range. From the mask-like covering in ancient times to the natural look which is the choice of the present day, face powders have been and still remain one of the basics of the cosmetic industry. A great deal of changes has taken place in face powder fashion during the last couple of decades. Tinted, shiny, enhanced by our modern cosmetics, the woman of today is able, with only modest effort, to be more attractive than she has ever been in the past. A face powder is basically a cosmetic product which has as its prime function the ability to complement skin color by imparting a velvet finish to it. A good fair powder should produce a smooth furnish to the facial skin, masking visible imperfections of the face and shine due to moisture or grease from perspiration or secretion of sebaceous and sweat glands or from preparations used on the skin. The powder must produce a lasting effect, so that frequent application is unnecessary. The preparation should make the face pleasant to look and touch. The degree of opacity can vary from opaque, in case of clown make-up, to almost transparent. It must adhere to the skin and be reasonably resistant to the mixed secretions of the skin. Pressed powders nowadays are usually talc-free and pressureblasted into compacts without the need for caking agents. They're infinitely finer, softer and more natural-looking. With brands offering up options that promise to smooth, set and even hydrate, powders are undergoing an essential overhaul. Powder-encapsulated spheres of hyaluronic acid dispense a seamless sweep of cashmere-soft, oilbalancing powder on skin, while the hydrating microspheres settle into lines to plump them out and prevent creasing. Now, it's the turn of powder as next generation technology is pushing it forward and into the future problem solving issues that have turned many into powder refuseniks.
Microcrystalline cellulose (MCC); Generally Recognized as Safe (GRAS); Reactive Oxygen Species (ROS); Registration, Evaluation and Authorization of Chemicals (REACH); CLP (Classification, Labelling and Packaging); Globally Harmonized System (GHS); Material Safety Data Sheet (MSDS); Acetylcholinesterase (AChE)

\section{Acknowledgment}

I'm thankful to Dr. Hitomi Ohtaka, Shiseido Global Innovation Center, Shiseido Company Limited, Kanagawa, Japan for her valuable time to audit my paper and for her thoughtful suggestions. I'm also grateful to seminar library of Faculty of Pharmacy, University of Dhaka and BANSDOC Library, Bangladesh for providing me books, journal and newsletters.

\section{Article Summary}

Face powder is a cosmetic product used to provide a special touch on the skin, to control oil and combat shines, or, in addition to provide a matt finishing effect on the skin. This matt effect, combined with the high transparency of the powder can develop a special soft-focus effect on the skin, blurring the appearance of wrinkles and lines as well as reducing the visibility of discoloration to enhance skin appearance. Certain types of pigmented facial powders are meant be worn alone with no base foundation. Powder tones the face and gives an even appearance. Besides toning the face, some powders with sunscreen can also reduce skin damage from sunlight and environmental stress. It comes packaged either as a compact or as loose powder. It can be applied with a sponge, brush, or powder puff. Uniform distribution over the face is achieved more easily when a loose powder is applied. In recent years, the so-called mineralbased foundation products have become increasing popular in the cosmetic consumer market and can demand a premium price from the consumer.

\section{Article Highlights}

1. The Queen Victoria of Great Britain was the one who prohibited using the makeup for the reason that it seemed vulgar.

2. Powders also contain between $10 \%$ to $20 \%$ of organic texture agents or mineral agents, preservatives, anti-oxidants, and perfumes.

3. Face powders can be very long-lasting, especially if applied on top of foundation.

4. Face powders can also be used as eyeshadow primer, lipstick mattifier, mascara primer and emergency dry shampoo.

5. Mineral foundation powders are often claimed as being 'chemical free' as they purport to contain no potential skin irritants such as fragrances, talc, dyes or preservatives. Some manufacturers claim that they contain anti- inflammatory properties to calm irritated skin.

6. Care must be taken to ensure that the talc has been adequately treated to overcome any possible microbial contamination, the major concern being tetanus spores.

7. Zinc oxide is the broadest spectrum UVA and UVB reflector approved for use as a sunscreen by the FDA and is allowed in concentrations up to $25 \%$.

8. With technological advances, innovative methods of characterization of powder flow are invented but their use suffer from various limitations including reproducibility, performance conditions, and predictability.

9. Prolonged use of the products may increase the amount of heavy metals in the human body overtime.

10. Particle sizes in loose powders are generally smaller compared to those of compact (pressed) powders and triggers the performance of the powder product.

\section{Abbreviations}


22. Penninkilampi R, Eslick GD. (2018) Perineal Talc Use and Ovarian Cancer: A Systematic Review and Meta-Analysis. Epidemiology. Jan;29(1):41-49.

1. Loose Face Powders. Cosmetics and Skin, 28th April 2017.

2. M. S. Balsam, Edward Sagarin.( 1972) Cosmetics: Science and Technology Volume 1 of Cosmetics, Science and Technology, M. S. Balsam, Edition2 (illustrated), published by John Wiley \& Sons Canada, Limited, , ISBN0471046469, 9780471046462

3. Make-up tips. How to Choose and Use Face Powder? ExpertAdvice, Paula's Choice (LLC) Skincare.

4. Make-up. How to Choose The Right Face Powder For You?

5. Peter Elsner, Howard I. (2000). Cosmeceuticals: Drugs vs. Cosmetics Volume 23 of Cosmetic science and technology series, published by CRC Press, ISBN 0824703057, 9780824703059 .

6. John Toedt, Darrell Koza, Kathleen Van Cleef-Toedt. (2005 )Chemical Composition of Everyday Products ABC-Clio ebook Gale virtual reference library, published by Greenwood Publishing Group, ISBN 0313325790, 9780313325793.

7. Intantya. (2017)Types of Face Powder and Its Functions. The Carousel by Avoskin, 2 January.

8. Intantya. (2017)Types of Face Powder and Its Functions. The Carousel by Avoskin, 2 January.

9. Finishing Powder vs Setting Powder: What's The Difference?

10. Paula Begoun. (2004 )The Complete Beauty Bible: The Ultimate Guide to Smart Beauty, published by Rodale, ISBN 1579549993, 9781579549992.

11. Stan Place, Bobbi Ray Madry.( 1989) The Art and Science of Professional Makeup Skin Series, published by Cengage Learning,. ISBN $0873503619,9780873503617$.

12. H. Butler. (2013) Poucher's Perfumes, Cosmetics and Soaps Edition 10, illustrated, published by Springer Science \& Business Media, ISBN 9401727341, 9789401727341.

13. Blumenthal D. Beauty(1984): A Dusting Of Powder. The New York Times, OCT. 28, Ralph Gordon Harry. Harry's Cosmeticology 7th edition, edited by Meyer R. Rosen, published by Chemical Publishing Company, 2015 ISBN $0820601764,9780820601762$.

14. Talc. https://www.fda.gov/cosmetics/cosmetic-ingredients/talc

15. S.K. Singh. (2010)Handbook on Cosmetics (Processes, Formulae with Testing Methods), published by Asia Pacific Business Press Inc., ISBN 8178331292, 9788178331294, pp 336.

16. Gordon RE, Fitzgerald S, Millette J. (2014) Asbestos in commercial cosmetic talcum powder as a cause of mesothelioma in women. Int J Occup Environ Health. 2014 Oct;20(4):318-332. Epub 2014 Sep 3. Erratum in: Int J Occup Environ Health. 2015;21(4):347-8. PubMed PMID: 25185462; PubMed Central PMCID: PMC4164883.

17. Talc (without asbestos fibres) (respirable fraction) [MAK Value Documentation, 2006] (respirable fraction) 2006. Documentations and Methods First published: 31 January 2012.

18. Ashour MS, Abdelaziz AA, Hefni H, el-Tayeb OM.( 1989 ) Microbial contamination of cosmetics and personal care items in Egypt--body lotions and talcum powders. J Clin Pharm Ther. Jun;14(3):207-212. PubMed PMID: 2760119.

19. Muscat JE, Huncharek MS. (Perineal talc use and ovarian cancer: a critical review. Eur J Cancer Prev. 2008 Apr;17(2):139-146.

20. Cramer DW, Vitonis AF, Terry KL, Welch WR, Titus LJ. (2016 )The Association Between Talc Use and Ovarian Cancer: A Retrospective Case-Control Study in Two US States. Epidemiology. May;27(3):334-46.

21. Trabert B. (2016) Body Powder and Ovarian Cancer Risk-What Is the Role of Recall Bias? Cancer Epidemiol Biomarkers Prev. Oct;25(10):1369-1370.
23. Casey R, Larkin TP. (2019) Ovarian Cancer and "Tainted Talc": What Treating Physicians Need to Know. Mo Med. MarApr;116(2):83-86.

24. Fletcher NM, Harper AK, Memaj I, Fan R, Morris RT et al (2019) Molecular Basis Supporting the Association of Talcum Powder Use With Increased Risk of Ovarian Cancer. Reprod Sci. Feb 28:1933719119831773.

25. Talc Overview. Available From: https://www.flexicon.com/Materials-Handled/Talc.html

26. Levy SB. Chapter 29. UV Filters. In: André O. Barel, Marc Paye, Howard I. Maibach. Handbook of Cosmetic Science and Technology, 3rd Edition, published by CRC Press, 2014. ISBN 9781842145647, pp-318

27. Titanium Dioxide. Available From: http://www.safecosmetics.org/get-the-facts/chemicals-ofconcern/titanium-dioxide- $2 /$

28. Smijs, Threes G, and Stanislav Pavel.(2011)“Titanium dioxide and zinc oxide nanoparticles in sunscreens: focus on their safety and effectiveness." Nanotechnology, science and applications vol. 4 95-112. 13 Oct.

29. Skocaj M, Filipic M, Petkovic J, Novak S. (2011Titanium dioxide in our everyday life; is it safe? Radiol Oncol. Dec;45(4):227-47.

30. Weir A, Westerhoff P, Fabricius L, Hristovski K, von Goetz N. (2012)

31. Titanium dioxide nanoparticles in food and personal care products. Environ Sci Technol. Feb 21;46(4):2242-50.

32. IARC Working Group on the Evaluation of Carcinogenic Risk to Humans. Carbon Black, Titanium Dioxide, and Talc. Lyon (FR): International Agency for Research on Cancer; 2010. (IARC Monographs on the Evaluation of Carcinogenic Risks to Humans, No. 93.) 1, Exposure Data. Available from: https://www.ncbi.nlm.nih.gov/books/NBK326523/

33. Carmo TLL, Siqueira PR, Azevedo VC, Tavares D, Pesenti EC et al (2019) Overview of the toxic effects of titanium dioxide nanoparticles in blood, liver, muscles, and brain of a Neotropical detritivorous fish. Environ Toxicol. Apr;34(4):457-468.

34. Sagawa Y, Futakuchi M, Xu J, Fukamachi K, Sakai Y, et al (2012) Lack of promoting effect of titanium dioxide particles on chemically-induced skin carcinogenesis in rats and mice. $\mathbf{J}$ Toxicol Sci.;37(2):317-327.

35. Xu J, Sagawa Y, Futakuchi M, Fukamachi K, Alexander DB, et al (2011) Lack of promoting effect of titanium dioxide particles on ultraviolet B-initiated skin carcinogenesis in rats. Food Chem Toxicol. Jun;49(6):1298-302. Epub 2011 Mar 23.

36. Chapter 3. Powders and Compacts. In. B.M. Mithal, R.N. Saha. A Handbook Of Cosmetics. Vallabh Prakashan, 2006 ISBN 9788185731223, 8185731225. Page 23.

37. Winkler, Hans Christian (2018) "Critical review of the safety assessment of titanium dioxide additives in food." Journal of nanobiotechnology vol. 16,1 51. 1 Jun.

38. Leone, Federica (2019) "Nanostructured $\mathrm{ZnO}$ as Multifunctional Carrier for a Green Antibacterial Drug Delivery System-A Feasibility Study." Nanomaterials (Basel, Switzerland) vol. 9,3 407. 11 Mar.

39. Kołodziejczak-Radzimska, Agnieszka, and Teofil Jesionowski. (2014 )"Zinc Oxide-From Synthesis to Application: A Review." Materials (Basel, Switzerland) vol. 7,4 2833-2881. 9 Apr

40. Gupta, Mrinal et al. "Zinc therapy in dermatology: a review." Dermatology research and practice vol. 2014 (2014): 709152. 
41. Pasquet J, Chevalier Y, Couval E, Bouvier D, Bolzinger MA. (2015 ) Zinc oxide as a new antimicrobial preservative of topical products: interactions with common formulation ingredients. Int J Pharm. Feb 1;479(1):88-95.

42. Sirelkhatim A, Mahmud S, Seeni A, Kaus NHM, Ann LC,et al (2015) Review on Zinc Oxide Nanoparticles: Antibacterial Activity and Toxicity Mechanism. Nanomicro Lett.;7(3):219242.

43. The Science \& Safety Behind Your Favorite Products (Zinc Oxide). Available From: https://cosmeticsinfo.org/ingredient/zinc-oxide-0

44. Ma, Jinxia et al. "Preparation of Zinc Oxide-Starch Nanocomposite and Its Application on Coating." Nanoscale research letters vol. 11,1 (2016): 200.

45. Lin, Pei-Hui et al. "Zinc in Wound Healing Modulation." Nutrients vol. 10,1 16. 24 Dec. 2017

46. The Ultimate Guide to Zinc oxide. Available From: https://www.alyaka.com/magazine/ultimate-guide-zinc-oxide/

47. Jiang J, Pi J, Cai J. (2018) The Advancing of Zinc Oxide Nanoparticles for Biomedical Applications. Bioinorg Chem Appl. Jul 5;2018:1062562.

48. Siddiqi KS, Ur Rahman A, Tajuddin, Husen A.(2018) Properties of Zinc Oxide Nanoparticles and Their Activity Against Microbes. Nanoscale Res Lett. May 8;13(1):141.

49. Williams, Lynda B, and Shelley E Haydel. (2010)"Evaluation of the medicinal use of clay minerals as antibacterial agents." International geology review vol. 52,7/8): 745-770.

50. Ngole-Jeme, Veronica M, and Georges-Ivo E Ekosse. (2015 )"A Comparative Analyses of Granulometry, Mineral Composition and Major and Trace Element Concentrations in Soils Commonly Ingested by Humans." International journal of environmental research and public health vol. 12,8 8933-55. 31 Jul.

51. Zhou Y, Liu Q, Xu P, Cheng H, Liu Q. (2018) Molecular Structure and Decomposition Kinetics of Kaolinite/Alkylamine Intercalation Compounds. Front Chem. Jul 27;6:310.

52. Li X, Ouyang J, Zhou Y, Yang H.( 2015) Assembling strategy to synthesize palladium modified kaolin nanocomposites with different morphologies. Sci Rep. Sep 3;5:13763.

53. Massaro M, Colletti CG, Lazzara G, Riela S.( 2018) The Use of Some Clay Minerals as Natural Resources for Drug Carrier Applications. J Funct Biomater. Oct 19;9(4). pii: E58.

54. Glick JB, Kaur RR, Siegel D. (2013) Achieving hemostasis in dermatology-Part II: Topical hemostatic agents. Indian Dermatol Online J. Jul;4(3):172-176.

55. COOP COCO (Blog). (2015) How to choose clay? Tips and tricks, Tutorials and recipes, 26 June.

56. Awad ME, López-Galindo A, Setti M, El-Rahmany MM, Iborra CV. (2017)Kaolinite in pharmaceutics and biomedicine. Int J Pharm. Nov 25;533(1):34-48.

57. Sinha R. Kaolin Clay(2019) For Skin: What Is It, Benefits, And How To Use It. STYLECRAZE (Skin Care Ideas), June 27.

58. Herman SJ, Olscamp GC, Weisbrod GL.(1982) Pulmonary kaolin granulomas. J Can Assoc Radiol. Dec;33(4):279-280.

59. Moosavi, Maryam. (2017) "Bentonite Clay as a Natural Remedy: A Brief Review.” Iranian journal of public health vol. 46,9 : 1176-1183.

60. Adib-Hajbaghery, Mohsen et al. (2014 )"The effects of Bentonite and Calendula on the improvement of infantile diaper dermatitis." Journal of research in medical sciences: the official journal of Isfahan University of Medical Sciences vol. 19,4 : 314-318.

61. Cosmetic Clays in Skin Care. Chagrin Valley Soap \& Salve Co, June 25, 2019.

62. Berry J. Bentonite clay(2019) 11 benefits and uses. Medical News Today, 22 May.
Maxim LD, Niebo R, McConnell EE. (2016) Bentonite toxicology and epidemiology - a review. Inhal Toxicol. Nov;28(13):591-617.

64. Chapter 5. Do it yourself. In: Julie Gabriel. The Green Beauty Guide, Health Communications, Inc. Deerfield Beach, Florida 2008, Page 87. eISBN-13: 978-0-7573-9788-2, eISBN-10: 07573-9788-3

65. Safety Assessment of Alkonium Clays as Used in Cosmetics. Cosmetics Ingredient Review, January 6, 2016, Page 12

66. Williams LB, Haydel SE, Ferrell RE.(2009) Bentonite, Bandaids, and Borborygmi. Elements (Que). Apr 1;5(2):99104.

67. Web Sojourner Williams LLC. DIY All Natural, Oil Absorbing Translucent Facial Powder. Face, September 9, 2014.

68. What Is Calcium Bentonite Clay? Available From: https://www.healthline.com/health/calcium-bentonite-clay\#1

69. Ghica MV, Hîrjău M, Lupuleasa D, Dinu-Pîrvu CE.( 2016 ) Flow and Thixotropic Parameters for Rheological Characterization of Hydrogels. Molecules. Jun 16;21(6). pii: E786.

70. Binks BP, Clint JH, Whitby CP.( 2005) Rheological behavior of water-in-oil emulsions stabilized by hydrophobic bentonite particles. Langmuir. Jun 7;21(12):5307-16.

71. Cho YJ, Kim DM, Song IH, Choi JY, Jin SW, Kim BJ, et al . (2018) An Oligoimide Particle as a Pickering Emulsion Stabilizer. Polymers (Basel). Sep 27;10(10). pii: E1071.

72. Fernández L, Scher H, Jeoh T, VanderGheynst JS. (2015 ) Room-temperature storage of microalgae in water-in-oil emulsions: influence of solid particle type and concentration in the oil phase. Bioprocess Biosyst Eng. Dec;38(12):2451-2460.

73. Chapter 2. Corundum and Emery Supply-Demand Relationships. In: John J. McKetta Jr. Encyclopedia of Chemical Processing and Design: Volume 12 - Corrosion to Cottonseed. CRC Press, 1981, Page 87. ISBN 0824724623, 9780824724627

74. Zhang B, Cui D, Liu M, Gong H, Huang Y, Han F.(2012 )Corn porous starch: preparation, characterization and adsorption property. Int J Biol Macromol. Jan 1;50(1):250-6.

75. Dura A, Błaszczak W, Rosell CM. (2014) Functionality of porous starch obtained by amylase or amyloglucosidase treatments. Carbohydr Polym. Jan 30;101:837-845.

76. Kirschner C. 5 Alternatives to talc powder. Mother Nature Network, June 13, 2019.

77. Schlossman ML. Chapter 43. Decorative Products. In. André Barel, Marc Paye, Howard I. Maibach. Handbook of Cosmetic Science and Technology Edition 2, CRC Press, 2005, Page 568. ISBN 0849354838, 9780849354830

78. Schlossman ML. Chapter 19. Decorative Products. In. Peter Elsner, Howard I. Maibach. Cosmeceuticals: Drugs vs. Cosmetics Volume 23 of Cosmetic science and technology series EBSCO ebook academic collection, CRC Press, 2000, Page 291, ISBN 0824742397, 9780824742393

79. García N.L., Famá L., Dufresne A., Aranguren M., Goyanes S. (2009) A comparison between the physic-chemical properties of tuber and cereal starches. Food Res. Int.;42:976-982.

80. Wang, Kai, Henry RJ, Gilvert RG. (2014 )“Causal Relations Among Starch Biosynthesis, Structure, and Properties." Springer Science Reviews, vol. 2, no. 1-2, May, pp. 15-33.

81. Peng M, Gao M, Båga M, Hucl P, Chibbar RN.( 2000) Starchbranching enzymes preferentially associated with A-type starch granules in wheat endosperm. Plant Physiol. Sep;124(1):265272.

82. Sun Q, Zhu X, Si F, Xiong L. (2015) Effect of acid hydrolysis combined with heat moisture treatment on structure and physicochemical properties of corn starch. J Food Sci Technol. Jan;52(1):375-82. Epub 2013 Apr 28. 
101. FMC, 2013. Fun facts about Avicel® microcrystalline cellulose

83. Kaur M, Oberoi DP, Sogi DS, Gill BS. (2011) Physicochemical, morphological and pasting properties of acid treated starches from different botanical sources. J Food Sci Technol. Aug;48(4):460-465. Epub 2010 Oct 29.

84. Božanić DK, Djoković V, Dimitrijević-Branković S, Krsmanović R, McPherson M, (2011) Inhibition of microbial growth by silver-starch nanocomposite thin films. J Biomater Sci Polym Ed.;22(17):2343-55.. PubMed PMID: 25593372; PubMed Central PMCID: PMC4288800.

85. Chapter 4 Fillers and reinforcements. In. Clive Maier, Theresa Calafut. Polypropylene: The Definitive User's Guide and Databook Plastics Design Library, Page 50. William Andrew, 1998 ISBN 0815518714, 9780815518716

86. Schaefer K. (2010)Natural Calcium Carbonates for Oral Care and Color Cosmetics. Cosmetics \& Toiletries ${ }^{\circledR}$ Magazine, June 11, .

87. Anstead DF. Chapter 7. Miscellaneous Raw Materials. In. H. W. Hibbott. Handbook of Cosmetic Science: An Introduction to Principles and Applications, page 121. Elsevier, 2016 ISBN 1483186474, 9781483186474.

88. Chapter 13. Facial Adornment. In. Zoe Diana Draelos. Cosmetics and Dermatologic Problems and Solutions, Third Edition (revised). Taylor \& Francis, 2011, Page 95-99. ISBN 1841847402, 9781841847405

89. Di Maiuta N, Schwarzentruber P. (2011) Molecular detection of bacteria in calcium carbonate powder used in cosmetic formulations. Int J Cosmet Sci. Oct;33(5):426-31.

90. Chapter 5 Group $14 \mathrm{C} \mathrm{Si} \mathrm{Ge} \mathrm{Sn}$ and $\mathrm{Pb}$ Alkaline Earth Compounds. In. Richard C. Ropp. Encyclopedia of the Alkaline Earth Compounds, Page 360. Newnes, 2012 ISBN 0444595538, 9780444595539.

91. Magnesium carbonate. Available From: https://www.revolvy.com/page/Magnesium-carbonate

92. Select Minerals for the North America Personal Care. Available From: content/uploads/2015/08/personalcare.pdf

93. Chapter 7. Color cosmetics. In. S.D. Williams, W.H. Schmitt. Chemistry and Technology of the Cosmetics and Toiletries Industry, Page 164. Springer Science \& Business Media, 2012 ISBN 9400915551, 9789400915558.

94. Sherif S. Z. Hindi, (2017 )"Microcrystalline Cellulose: The Inexhaustible Treasure for Pharmaceutical Industry." Nanoscience and Nanotechnology Research, vol. 4, no. 1: 1724.

95. Qin Y, Qiu X, Zhu JY. (2016) Understanding Longitudinal Wood Fiber Ultra-structure for Producing Cellulose Nanofibrils Using Disk Milling with Diluted Acid Prehydrolysis. Sci Rep. Oct 31;6:35602.

96. Lynch G. Rheology Modification with Avicel® in Personal Care Applications. Available From: http://www.cosmeticsciencetechnology.com/articles/samples/1 81.pdf

97. Setu, Md Nurul Islam, et al.(2015 )"Preparation of Microcrystalline Cellulose from Cotton and Its Evaluation as Direct Compressible Excipient in the Formulation of Naproxen Tablets." Dhaka University Journal of Pharmaceutical Sciences, vol. 13, no. 2, May, pp. 187-192.

98. Chaerunisaa, Anis Yohana, 2019 )"Microcrystalline Cellulose as Pharmaceutical Excipient." Pharmaceutical Formulation Design - Recent Practices [Working Title].

99. Rojas J, Lopez A, Guisao S, Ortiz C. Evaluation of several microcrystalline celluloses obtained from agricultural byproducts. J Adv Pharm Technol Res. 2011 Jul;2(3):144-50. doi: 10.4103/2231-4040.85527.

100. Kamel, S., et al. "Pharmaceutical Significance of Cellulose: A Review." Express Polymer Letters, vol. 2, no. 11, 2008, pp. 758-778., doi:10.3144/expresspolymlett.2008.90. also known as cellulose gel. Available From: http://www.fmcbiopolymer.com/Food/Home/News/FiftyYears ofAvicel.aspx

102. Microcrystalline Cellulose powder. SIDLEY CHEMICAL, 7 March, 2014.

103. Heng PW, Liew CV, Soh JL. Pre-formulation studies on moisture absorption in microcrystalline cellulose using differential thermo-gravimetric analysis. Chem Pharm Bull (Tokyo). 2004 Apr;52(4):384-90.

104. Garg T, Rath G, Goyal AK. Comprehensive review on additives of topical dosage forms for drug delivery. Drug Deliv. 2015 Dec;22(8):969-987.

105. Muñiz-Lerma JA, Nommeots-Nomm A, Waters KE, Brochu M. A Comprehensive Approach to Powder Feedstock Characterization for Powder Bed Fusion Additive Manufacturing: A Case Study on AlSi7Mg. Materials (Basel). 2018 Nov 27;11(12). pii: E2386. doi: 10.3390/ma11122386.

106. Hesse N, Dechet MA, Bonilla JSG, Lübbert C, Roth S, Bück A,et al . (2019) Analysis of Tribo-Charging during Powder Spreading in Selective Laser Sintering: Assessment of Polyamide 12 Powder Ageing Effects on Charging Behavior. Polymers (Basel). 2019 Apr 3;11(4). pii: E609.

107. Hobbs CA, Saigo K, Koyanagi M, Hayashi SM. (2017 )Magnesium stearate, a widely-used food additive, exhibits a lack of in vitro and in vivo genotoxic potential. Toxicol Rep. Oct 16;4:554-559.

108. Silk Powder (200 Mesh) Raw Material. Available from: https://www.newdirectionsaromatics.com/products/rawmaterials/silk-powder-200-mesh.html

109. Shi L, Yang N, Zhang H, Chen L, Tao L, Wei Y, Liu H, Luo Y. A novel poly( $\gamma$-glutamic acid)/silk-sericin hydrogel for wound dressing: Synthesis, characterization and biological evaluation. Mater Sci Eng C Mater Biol Appl. 2015 Mar;48:533-40.

110. Material Safety Data Sheet Bismuth Oxychloride MSDS," Sciencelab.com, May 21, 2013. Available From: http://www.sciencelab.com/msds.php?msdsId=9923103.

111. van Lotringen I. Cream or powder makeup - which is better? Cosmopolitan (UK), May 5, 2015.

112. Bale S. Chapter 20. Natural Finishes. In. Jacob Deva Racusin, Ace McArleton. The Natural Building Companion: A Comprehensive Guide to Integrative Design and Construction (Yestermorrow Design/Build library), Published by Chelsea Green Publishing, 2012, Page 363. ISBN 1603583394, 9781603583398

113. Yusuf M, Shabbir M, Mohammad F. (2017)Natural Colorants: Historical, Processing and Sustainable Prospects. Nat Prod Bioprospect. Feb;7(1):123-145.

114. Marzec A, Szadkowski B, Rogowski J, Maniukiewicz W, Szynkowska MI, Zaborski M. Characteristics of Hybrid Pigments Made from Alizarin Dye on a Mixed Oxide Host. Materials (Basel). 2019 Jan 24;12(3). pii: E360.

115. Herz RS. Perfume. In: Gottfried JA, editor. Neurobiology of Sensation and Reward. Boca Raton (FL): CRC Press/Taylor \& Francis; 2011. Chapter 17. Available from: https://www.ncbi.nlm.nih.gov/books/NBK92802/

116. Lenochová $\mathrm{P}$, Vohnoutová $\mathrm{P}$, Roberts SC, Oberzaucher E, Grammer K, Havlíček J. Psychology of fragrance use: perception of individual odor and perfume blends reveals a mechanism for idiosyncratic effects on fragrance choice. PLoS One. 2012;7(3):e33810.

117. Shah RB, Tawakkul MA, Khan MA. Comparative evaluation of flow for pharmaceutical powders and granules. AAPS PharmSciTech. 2008;9(1):250-8. Epub 2008 Feb 15. PubMed PMID: 18446489; PubMed Central PMCID: PMC2976911. 
118. Amparo Salvador, Alberto Chisvert. Analysis of Cosmetic Products, Edition 2, published by Elsevier Science, 2017 ISBN 0444635165, 9780444635167

119. Globally Harmonized System of Classification and Labelling of Chemicals, ST/SG/AC. 10/30/Rev.6 (sixth revised edition), United Nations, New York and Geneva (2015)

120. EU Regulation (EC) No 1272/2008 of the European Parliament and of the Council of 16 December 2008 on Classification, Labelling and Packaging of Substances and Mixtures, Amending and Repealing Directives 67/548/EEC and 1999/45/EC, and Amending Regulation (EC) No 1907/2006. Official Journal of the European Union, L 353/1, 31/12/2008.

121. Steiling W, Almeida JF, Assaf Vandecasteele H, Gilpin S, Kawamoto T, O'Keeffe L.et al (2018) Principles for the safety evaluation of cosmetic powders. Toxicol Lett. Nov;297:8-18.

122. OEHHA (Office of Environmental Health Hazard Assessment), 2011. https://oehha.ca.gov/proposition-65/chemicals/titanium- dioxide-airborne-unbound-particles-respirable-size. Office of Environmental Health Hazard Assessment (OEHHA) of the California Environmental Protection Agency, 2011.

123. Monographs on the Evaluation of Carcinogenic Risks to Human, vol. 65 (1996), pp. 171-172.

124. Łodyga-Chruścińska, E.; Sykuła, A.; Więdłocha, M. Hidden Metals in Several Brands of Lipstick and Face Powder Present on Polish Market. Cosmetics 2018, 5(4), 57 DOI: https://doi.org/10.3390/cosmetics5040057.

125. Abdul Kader Mohiuddin. Heavy Metals in Cosmetics: The Notorious Daredevils and Burning Health Issues. Am J Biomed Sci \& Res. 2019 - 4(5). AJBSR.MS.ID.000829. DOI: 10.34297/AJBSR.2019.04.000829

126. Mohiuddin AK. Cosmetics Safety: Gray Areas with Darker Inside. Journal of Medical Research and Health Sciences Volume 2 issue 8, Page 688-693 August, 2019. DOI https://doi.org/10.15520/jmrhs.v2i8.97 